University of Louisville

ThinkIR: The University of Louisville's Institutional Repository

Electronic Theses and Dissertations

1937

\title{
A comprehensive survey of cultural movements in Louisville during the nineteenth century.
}

Flora Heitz

University of Louisville

Follow this and additional works at: https://ir.library.louisville.edu/etd

Part of the American Popular Culture Commons, Public History Commons, and the United States History Commons

\section{Recommended Citation}

Heitz, Flora, "A comprehensive survey of cultural movements in Louisville during the nineteenth century." (1937). Electronic Theses and Dissertations. Paper 1797.

https://doi.org/10.18297/etd/1797

This Master's Thesis is brought to you for free and open access by ThinkIR: The University of Louisville's Institutional Repository. It has been accepted for inclusion in Electronic Theses and Dissertations by an authorized administrator of ThinkIR: The University of Louisville's Institutional Repository. This title appears here courtesy of the author, who has retained all other copyrights. For more information, please contact thinkir@louisville.edu. 
UNIVERSITY OF LOUISVILLE

A COMPREHENSIVE SURVEY OF CULTURAL MOVEMENTS

IN LOUISVILTE

DURING THE NINETEENTH GENTURY

\author{
A dissertation \\ Submitted to the Faculty \\ Of The Graduate School of the Un1versity of Loulsville \\ In Partial Fulfiliment of the \\ Requirements for the Degree \\ of Master of Arts
}

Department of History

By

FLORA HEITZ 
A Comprehensive Survey of Cultural Movements TITIF In Louisville During The Nineteenth Century

DIRECTOR Dr. N. C. Mallalieu

APPROVED BY:

Director

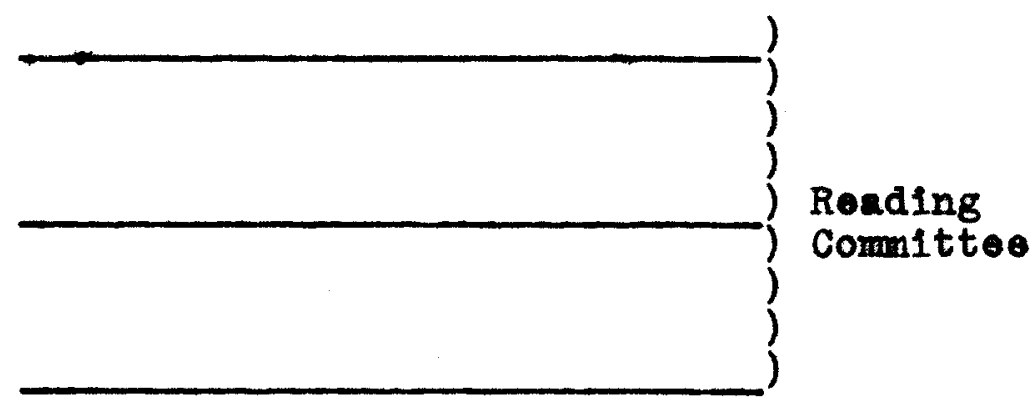

Representative of the English Department

DAPE 
To

MY MOTHER

and

MY FATHER

whose reminiscences of the Loulsville of their Jouth are some of my most cherished memories 
TABIE OF CONTENTS 
A COMPREHENSIVE SURVEY OF CULTURAL MOVEMENTS

IN LOUISVILIE

DUR ING THE NINETEENTH CENTURY

TABLE OF CONTENTS

Page

I. Introduction 3

II. Library Associations

III. The Lyceum - 29

IV. Scientific Advancement Groups _............ 38

v. Literary and Musical Groups 48

VI. Nationalistic Cultural Groups (-........... 66

VII. Historical Societios 86

VIII. Summary 99

IX. Appendix A

X. Appendix B 106

XI. Bibliography 115 
INTRODUCTION 
A COMPREHENSIVE SURVEY OF CULTURAL MOVEMENTS

\section{IN LOUISVILLE}

DURING THE NINETEENTH CENTURY

\section{INTRODUCTION.}

This survey is an attempt to trace various cultural movements that originated and developed in Louisville during the nineteenth century. It has been undertaken with the 1dea of representing the groups in which men and women associated together to effect improvement and refinement in "mind, morals, and taste" for themselves and indirectly for the community of which they were a pert. Thls endeavor includes only those voluntary groups through which individuals sought to realize special interests outside the realm of educational or religious institutions. The associations, societies, and organizations here in complled tend to reflect the initlative and leadership of relatively small groups of people; however, the appearance and success of 
such movements may be regarded as a cultural index or barometer of the clty through a determining perlod of 1ts growth.

Material for this study has been gathered for the most part from newspapers, acts of incorporation, and records of proceedings. Unfortunately, much information dealing with cultural development is unavailable. There can be no doubt that much helpful material is buried unknown in private libraries waiting to be called to the attention of present owners. In view of the inaccuracies of human memory, resort was not made to personal recollection of possible perticipants in the movements of concern. The search for material unearthod an incident that illustrates quite forcibly the part that chance may play in diselosing or hiding the type of material necessary for such a study. The secretary of a very promising historical organization was at the same time the Clerk of the United States District Court. Inadvertently he began to record the mutes of the historical society in the same book in which he later kept the records of the court. With the passing of time the said minutes were pasted fast together to allon free usage of the court records. With the passing of time, too, the book was cast aside with seemingly out-worn records. Fortunately, however, some appreclative 
individual in gloaning through court rocords was curlous enough to break the seals securing the records of sald (1)

historical group. This disclosure has throm an interosting light upon the cultural interests of the community.

In analyzing the cultural movements of a city for a century, one finds a variety of activities vying for attention. It is difficult to designate definite fields for these various activitios due to the fact that many movements under consideration embrace sereral types of activity. It will be noticed particularly that the numerous library associations usually included a number of endeavors. The purposes of this survey are served, however, by arriving at the following classification of cultural influences throughout the stated perlod: library associations; the Lyceum movement; scientific advancement groups; historical socleties; nationalistic cultural groups; Iiterary and musical groups. Due consideration will bo

(1) Book containing record of proceedings and court records in offloe of Clerk of U. S. District Court for Western District of Kentucky unearthed by P.W.A. worker, spring of 1936 showing Thomas Speod as Clork of U. S. District Court of Westerm District of Kentucky and Secretary of Academy of History of Polytechnic Society of Kentucky, 1883. 
given to apparent overlapping of particular groups from one field into another. Emphasis will be placed, however, upan the primary object of the movement.

Records or traces of cultural endeavors in the opening jears of the nineteenth century may have disappeared entirely; novertheless, it seems reasonable to conclude that there was natural lack of a desire on the part of the c1tizenry for improvement along such lines. Ono observer in Louls vilie in 1819 gives his impression of tho "state of society" in the flourishing river town: "Comnercial cities of all nowly settlod countries whose inhabitants are gathered from every corner of the earth, who have migrated thither with but one single object in view, that of acquiring money, are stamped with no general character, except that of frugality, attention to business, and in inordinate attachment to money. Absorbed in the great business of adding dollar to dollar, no time is devoted to literature, or the acquirement of those graceful nothings, which, of no value in themselves, still constitute one great charm of polished soolety." Another

(2) MeMurtrie, H. M., Sketchos of Louisvilie And Its Environs, p. 118. 
wter mentions the fate of a noteworthy Iiterary association of the early period as "obliged, like all its fellows, to sink beneath the careless inattention of a purely commercial community". (3) the existence in 1828 in Loulsville of three literary socleties and one musical soclety. that beginning in the thirtios and continuing on up to the end of the century there was an interest in cultural pursuits on the part of soloct groups of citizens. Frequently, to be sure, manj of their hopes were not realized and many of their projects suffered untimely terminations. Even short-lived movements, however, had a decided bearIng on the cultural atmosphere of the community, because they stimulated the development of more fortunate successors.

(3) Casseday, Bon, The History of Loulsville, p. 184

(4) Durrett, Reuben T., The Centenary of Louls ville (Filson Club Publication No. 8) p. 101 
LIBRARY ASSOCIATIONS 


\section{LIBRARY ASSOCIATIONS}

In this account Iouisville's varlous library associations and companies are considered as a developing cultural movement. Culminating in the Loulsvillo Freo Public Library established in 1902 there were libraries that functioned almost continuously since the first library was (2)

chartered in 1816. In that yoar the Legislature of Kentucky incorporated the Loulsville Library Company. Mann Butler, Williom Galt, Brooke Hill, Hezekiah Hawley and William Tompkins were constituted "a corporation and body politic in law and in fact, under the name and stilo of the President and Directors of the Loulsollie Library Company".

(1) a. Book of Incorporation, No. 12, p. 57 Jefferson County Court

"Amended Articles of Incorporation of the Polytechnic Society of Kentucky."

b. Ordinance of City of Louisville establishing Free Public Library (approved March 21, 1902) General Ordinances and City Charter, p. 546 (annotated) 1931 Compilation City of Loulsville 1931

(2) An Act of the General Assembly of the Commonwealth of Kentucky to incorporate the Loulsville and Hopkinsvilie Library Companies (Approved February 8, 1816) Acts of the $\frac{\text { General }}{\text { of } \text { Kentucky sembly of the Commonwealth }}$

(3) Ibld. p. 567 
According to Dr. H. M. MoMurtrie, writing in 1819, this public library in the second story of the south wing of the Court House consisted of almost five hundred volumes.

"It was then in its prime and never afterward increased its volumes nor added to 1 ts usefulness. In 1838 the books which were left went into the library of the 'Kentucky Hist or ical Socletf', which made a fine-start, but, like its predecessor, was not long lived. These unfortunate volumes of the first library in the town, having gotten into the Historical Society, seemed to have contracted the habit of going from on collection to another. They passed from the 'Kentucky Historical Society' to the 'Mercantile Association' of 1847 to the Kentucky Mechan1es' Institute of 1854, to the Young Men's Christian Association of 1867, to the Publie Library of Kentuaky of 1870, and to the Library of the Polytechnic Society of 1878. Some of them yet bear the labels of these different libraries through which they passed and are more valuable as relics of the first library in the tow and its successors through which they passed than for anything else." (5) Later "At a meeting of the members of the

(4) McMurtrie, Op. C1t. p. 121

(5) Johnston, J. Stoddard, Memorial History of Loulsvilie, 2 Vols. Vol. 1, p. 73 
Polytechnic Society, December, 1901 The Executive Council was authorized to execute and cause to be recorded accordIng to Law Amendments to the Charter of said Society to change the corporate name thereof to the Louisville Public Library." (6)

Free Public Library.

The charter of the Loulspille Library Company of 1816 specified "that the said corporation may purchase, recelve by grant; or otherwise, and hold books, maps, charts and all other apparatus appertaining to literature, and every other species of property". (7) the Library of 1816 that "among its books were valuable histories collected by Mann Butler, and works on scientific subjects obtained by Dr. McMurtrie. The whole number of volumes was about five hundred, and the young library may then be sald to have been in 1ts prime. It never materialIy increased afterward, and when the malignant fever of 1822

(6) "Amended Articles of Incorporation of the Polytechnic Society of Kentucky" Book of Incorporation, No. 12, p. 57 Jefferson County Court

(7) An Act of the General Assembly of the Commonwealth of Kentucky to incorporate the Loulsville and Hopkinsville Library Companies (Approved, February 8, 1816), Section 2 
almost depopulated the city, the library, as well as the people, seems to have taken the seeds of death into its system. The files of the first newspapers published in our city perished, and so did the early works upon the history of our city, state, and country. Only a few of its volumes have come dom to our times, and these are of but little value in the collections in which they are now found. The most valuable books perished, and the unimportant ones which survived, reached our $t$ imes in such a mutilated condition as to be of littie consideration except as relics of the past. There is a name connected wth its organization, however, that should not pass from our memory as did its books from our use. This was Mann Butler, the first named among those who appear in the act of incorporation. It was he who inaugurated the gathering together of this first collection of books in our city, and if he had had as much money as he had love for books, he would have placed the library upon such a lasting foundation that it would have stood to our times."

Mention has already beon made of the library of the Kentucky Historical Soclety of 1838. That organization

(8) Quotation from Colonel Reuben T. Durrett relating to Louisvilie Library of 1816 History of The ohio Falls Citios and Their Counties 
will be considered more fully under the classification of "historical societies"; a contemporary project offected in 1839 under the title of the Louisville Law Library Company was organized by Henry Pyrtle, Garnett Duncen, John Kearney, and their assoclates. The Loulsvilie Law Library Company became authorized to establish and maintain a library "to consist of the history, treatises, constitution of the United states, and of the seroral States and Territories, and of the laws and docisions of the Supreme Court and Appellate Courts of the United States, and of the sereral states and Territories, and of the laws of Great Britain and Ireland, and the decisions of the Common Law and Chancery Courts, and of Elementary Works, and such other treatises on law as may be deemed useful". (9)

The Mercantile Library Association of Loulsville was chartered in 1842. "Sald Iibrary Association shall only have power to establish a library and reading and locture rooms in the city of Loulsville, and unite therewith such philosophical or scientific apparatus as they may choose". (10)

(9) Acts of General Assembly of the Commonwealth of Kontucky of 1838, Chapt or II59, page 120 An Act to incorporate tho Loulsvilie Law Ifbrary Company (Approved February 8, 1839)

(10) Acts of General Assembly of the Commonwealth of Kentucky 1839-42, Chapt or 124, p. 149 An Act to ostablish a Iibrary sssociation at Louisvillo (Approved February 5, 1842) 
of its constitution, as follows: "We, the subscribers, engaged in commer cial pursuits in the ofty of Loulsville, having for our object the highest interests of the commnity with which we are identified, by the more general diffusion of knowledge, that we may the better discharge our dutios to our profession, to society and to ourselves, and deeply impressed with the advanteges of combined exortion, in enlarging our means of information, encouragIng a free interchange of opinion and promoting a spirit of generous education, have associated ourselves for the purpose of collecting a library, establishing a reading room, and organizing a system of instruction by lectures, classes and debates, together with such other methods of improvement as may be found useful". (II) threw open 1ts library and reading-room to the inspection of the public and invited citizens of Loulsville to call and examine its collection of books. Three hundred thousand volumes selected with great care formed "the very cream of the cholcest works" in literature, science and history.

(11) The Loulsville Daily Journal, Nov. 24, 1841 TConstitution of the Mercantile Library Association of Loulsvilio)

(12) The Louisv1lle Daily Journal, March 29, 1842 (EdItorial on tho Mercantilo Librars Assoclation) 
In 1847 a company was established by tho name of "The Loulsville Library" to take possession of the Mercantile Library. (13)

"After some years of prosperous and useful 11fo, Including lecture courses during the winter months, the Association weakened for lack of interest and pecuniary support; and it was ultimately found desirable to interest the Chamber of Commerce in 1ts maintenance, by socurIng to that body the reversion of the Ilbrary, when the society should be no longer able to sustain it. This, howerer, did not suffice to save it; and the fine collection was long since dissipated and dispersed, no one knows where, with the exception of a scattered volume or broken set here and there." (14)

Records of the city reveal two instances wherein the municipal government dealt with the Louisville Library Company, the successor to the Mercantile Library. In 1850 the City Councll provided that "the Mayor and Councll shall set apart the house on the corner of sixth and Jefferson Stroets, by appropriate ordinances, for the use of the 11-

(13) Acts of the General Assembly of the Commonwealth or Kentucky 1846, Chapter 188, p. 157 An Act to amend an act, entitlod, an act to establish a Library Association at Louls vilio, approved Fobruary 5, 1842, (approved Fobruary 13, 1847)

(14) History of Tho Ohio Falls cities And Their Counties, 
brary, and shall change, Improve, and paint the same so as to make it a suitable llbrary room, and shall keep the same in good order and repalr, and shall not remove the library from the sald room without providing another room as suitable for the purpose. The Library shall be coded to the city upon the terms and conditions contained in this agreoment ....". (15)

1zed the dedication of surplus stock in the Loulsvilie and Frankfort Railroad Company to the support of the Loulsville Library. It specified that the Library Company "admit forever free of charge to all the privileges of said Iibrary, such of the male and femalo scholars, in the Malo and Female High Schools in this c1ty, as the Board of Trustees of Public Schools may designate...." (16)

The succoeding library project in Loulsville bocame known as the Library Association of Loulsville under 1ts charter of 1868. Citing the act of incorporation one

(15) Charter, Acts and Ordinances of the City of Louisvilie $1780-1869, \mathrm{p} \cdot 509$

"Agreement Between The City of Louis ville and The Loulsvilie Library Company"

(Adopted and approved by the Counc1l July 1, 1850 and recorded in Journal No. 14 of the Counc1l pp. 264, 265)

(16) Charter, Acts and Ordinances of the C1ty of Louisville $1780-1869 \mathrm{p} \cdot \frac{169}{669}$

"An Ordinance dedicating the surplus stock in the Louisville and Frankfort Railroad Company to the support of the Loulsvilie Library"

(Approved March 28, 1853) 
finds that "There has heretofore been formed in the city of Louisville an association called the 'Library Association of Loulsvilie', the objects of which are the obtaining and maintaining a public library and reading rooms, and procuring literary and sclentific lectures; now, therefore, in order to oncourage and promote the above declared objects of said association .... are hereby declared and created a body corporate, by the name and style of the 'Ilbrarg Assoclation of Loulsville'. (17) tion left fow traces of its careor.

"The most successful of the private 11brary socletios was the Loulsvillo Library Association, which was organized on the 8th of April, 1871. The plan upon whlch It was started was the contribution by each member of $\$ 30$. or twenty volumes of books acceptable to the directors. Tro hundred and seventeon members united in the foundation of the library .... The library was opened in the second story of the bullding at the northwest corner of Third and Walnut Streets, and remained there until January 1876, when it was removed to the rooms in the second story of the

(17) Acts of the General Assembly of the Commonwealth of Kontuak 1867-1868 VoI. II, Chapter 584, p. 25 "Añ Act to Incorporate the Library Association of Loulsville".

(Approved Fobruary 26, 1868) 
building at the southeast corner of Fifth and Walnut Streets .... The Library Association owed its success to the activity of its directory and the enthusiastic support of many of 1 ts members ....."

In 1871 the Kentucky Legislature chartered

The Public Library of Kentucky. The act reads in part as follows:

"Whereas, A library contalning the best books, pamphlets, perfodicals, and papers of all ages and all countries, freo to the use and en joyment of the public, is a blessing to be sought in every community; and whereas, many good citizens are anxious to contribute by gift, loan, subscription, or otherwise, to the establishment and maintenance of such a library in the city of Loulsvilie, provided the Legislature will grant such a charter to the enterprise as will inaugurate and place it upon a permanent and self-sustaining basis; therefore,

Be it enacted by the General Assembly of the Cormonwealth of Kentucky:

1. That Thos. E. Bramlette, Henry M. Watterson, Mike W. Closkey, Ben jemin Cassiday, Georgo P. Doorn, Walter H. Haldeman, H. M. McCarty, J. S. Cain, and R. T. Durrett, the ir successors and assigns, be, and they are hereby, created a corporation by the name of the "Public Library of Kentucky"; and by sald corporate name are hereby given all the rights, privileges, and porers of bodies-corporate for the uses and purposes herein sot forth.

(18) Pirtle, James $\mathrm{S}$. "The Loulsville Library Association". History of The Ohio Falls Citios And Thoir countios, VoI. I, p. 424 
2. The said corporation may acquire and hold, by gift, purchase, loan, or otherwiso, books, pamphlets, perlodicals, and papers, to bo used as a public library; and may acquire and hold, in fer simple or otherwise, the necessary grounds and buildings in which to keep and preserve and use its library; and may make such rules, regulations and by-laws; for the acquisition, safe-keoping, use, and enjoyment of its library, as may be deemed necessary: Provided, They are not in conflict with this act.

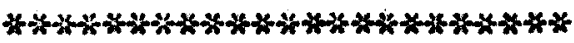

7. To obtain books, periodicals, pamphlets, papers, and such property as said corporation may hold, and to keep up the library and meet the current expenses of the same, the trustees, or a majority of them, are hereby authorized and empowered to issue stock for books, pamphlets, periodicals, and papers, to be used in the library, the same as if such stock were first sold and the procoeds thereof invested in such things; also to accopt presents, donations, and gifts of books, pamphlets, periodicals, papers, and property, without issuing stock therefor; also to accopt loans of books, pamphlets, periodicals, papers and property, to be used in the library for the care of them: also to publish a paper or periodical journal for the benefit of the Ilbrary, and appropriate the profits arising therefrom to the library; also to give; not to exceed $f i v e$ in number, public literary, musical, or dramatic entertainments, at which they may distribute, by lot, to patrons of the entertainments, a portion of the proceeds arising from the sale of tickets of admission; but no person is ever to be made to pay for the use and en joyment of the books, pamphlets, perlodicals, or papers of the corporation, and the library of the same is to be forever free to the gratuitous use and enjoyment of every citizen of the state of Kentucky, and of all good citizens of every state in the Union, who shall conform to the rules and regulations that may, from time to time, be made and adopted by the trustees for the care, preservation, and safety of the books and property of the corporation. The library, moroover, is to be kept open to the use and onjoyment of the public every day in the year, and during such hours at night as may be deemed proper for general use and enjoyment. 
8. The trustees, or a majority of them; are hereby authorized to appoint and employ such agents, assistants, and aditional trusteos, as they may deem necessary to collect books, pamphlets, periodicals, and papers, to secure subscriptions and donations, and to give and conduct literary, musical, and dramatic entertainments for the benefit of the library; but in such appointments and omployments they are not to involve the corporation in debt, nor incur for it any liabilities beyond its roady means of meeting them.

thy

Through a series of five lottery drawings the library recelved the total sum of $\$ 424,396.32$ which formed the endowment of the sald institution. (20) "The Public Library of Kentucky was formally opened to the free use of the public April 27, 1872." (2I)

The property of the Library was bullding 10eated on Fourth Street between Green and Walnut. Mr. Tome, the Iibrarian of the institution, described the property as follows: "It has a front of 168 feet and a depth of 200 feet. It is 3 stories high. The ground floor contalns eight stores from which rents are received. Festival hall, the library room, and what is now a grmasium - the

(19) Acts of the General Assembly of the Commonwealth of Kentucky 1871, Chapter 1947, p. 499, "An Act to Incorporate the Public Library of Kentucky" (This bill became a law March 16, 1871, the Governor having failed to sign or return a required by the Constitution.)

(20) Towne, P. A. - "The Public Library of Kentucky And The Polytechnic Society of Kentucky." Loulsville Monthly Magazine, Vol. I, p. 441 (August, $18 \% 9-$ No.8)

(21) Ib1d., p. 440 
former museum department - are all on the lower floor, also a back room used as a carponter shop for the bulldIng. The second story consists of rooms sultable for lecture and sociel purposes. One end of the building, including half the room on this floor, is occupled by the Young Men's Christion Association. The other end, lately occupled for a conservatory of music, is now vacant. The third story, consisting of about the some space as the second, is occupied by the Southern Baptist Theological Seminary and by the Odd Fellows' Association. The two wings have each a fourth story, unoccupled." According to Mr. Tome, "several facts combined in the summer of 1876 to warn the I1brarian that an attempt to organize a society to receive the property of the public library, that should also be strong enough to exempt that property from taxation and create a fund for its future conduct, must no longer be delayed ...... all pointed to the necessity of some plan to avoid its impending sale to pay off rapidly-accumulating debts.

"The spirit, if not the letter of the charter, Indicated that the property acquired under it should belong to the general public .... It might have boen given to the University of Loulsville, but there were other medical socleties whose interests were to be consulted. The Iibra- 
rian desired that the whole clty of Louisville and the whole state of Kentucky should have this property, and in this view he was sustained by all with whom he conversed on the subject." (23)

In 1876 through the efforts of the librarian a number of gentlemen met for the purpose of organizing a Iiterary society that should meet the requirements doemed necessary for taking over the obligations of the Public Library of Kentucky. The resulting organization continued as a purely literary and scientific society down to May 22, 1878, when it was chartered.

Out of the bankruptcy of the Public Library of Kentucky rose the Polytechnic Soclety of Kontucky founded in 1876 and chartered in 1878, its objectives being "the establishment of a public and clrculating library, and maintenance thereof; the printing and publication of papers or works 1llustrative of the history of Kentucky, of literature and science, the encouragement of original and the diffusion of knowledge." ${ }^{(25)}$ Section 4 of the
(23) Ibid., p. 657
(24) Ib1d., p. 658
(25) Acts of Incorporation and By-Laws of the Polytechnic Soclety of Kentucky. (Acts 1877-78, Vol. II, p. 600) Courier-Journal Job Rooms Print Louisville, Kentucky, 1881. 
charter authorizes the society to acquire the holdings of the Public Library of Kentucky, in the following provisions: "The corporation may acquire and hold by gift, purchase, loan, devise, or otherwise, books, pamphlets, perfodicals, papers, and minerals, to be used as a library and muserm; and may acquire and hold, in foe or otherwise, sultablo grounds and buildings in which to keep, preserve, and use its library and museum, and otherwise carry out 1ts purposes; and may make such rules, regulations and by1aws, for the acquisition, use and enjoyment of its library, museum, and property for the control of its membership, and for carrying out the objects herein named as may be doemed necessary: Provided, That if the Public Library of Kentucky shall make ang gift, sele, or transfer to the said Polytechnic society, such gift, sale or transfer shall include all moneys in action, claims, demonds, and right of action belonging to said Public Library of Kentucky either at law or in equity." (26)

In May, 1878, the Polytechnic Soclety became orner of the property and Ilbrary of the "Public Library of Kentucky" and assumed the indebtedness of that organization

(26) Ibid. 
(27)

that amounted to $\$ 100,000$.

The soclety bocame a llourlahing institution, establishing and maintaining a functioning library and exerting a cultural influence through 1ts academies, lectures, and art gallery in a way that stimulated the thinking poople of the community. The cultural achievements apart from the success of the library of said society will be treated in another section of this survey.

The library, no doubt, remained the primary undertaking of the society. From a civic viewpoint it will be satisfactory to note "that all the property of this corporation real, personal, and mixed, shall be free from all state and municipal taxation; but sald society shall not acquire real estate exempt from taxation apart from the building and grounds used for the objects named in this charter, and containing its Iibrary, museum, and gallery; and in case this charter or corporation shall lapse from non-use or other cause, any property that may be owned by the corporation shall escheat to the Commonwealth of Kentucky, and pass under the oupervision of the State Librarian. (28) In order to further the efforts of

(27) The Courier-Journal: Louisville, August 12, 1883

(28) Acts of the General Assembly of the Commonwealth of KentuckF 1881-82, Vo1. I, chapter 459, p. 183, Approved Harch 18, 1880, "An Act to amend an act, entitled 'An act to incorporate the Polytechnic Soclety of Kentucky, " approved Apr 11 10, 1878 and an act amendatory thereto, approved March 27, 1880, Section 12. 
of this corporation in establishing a great freo library in the advancement of science and in founding a freo art gallery, sohool of design, and natural history musoim in the elty of Louisville, the general councll of the city of Louisville is authorized and emporered, upon the request of a majortty of resident tax-payers of the said city of Louls ville, as shown by the books of the assessor, to impose, for the benefit of sald institution for the purposes aforesald, a general tax of not exceoding two cents on every $\$ 100$ of property subject to taxation for purposes of sinking fund in sald city, which sald tax shall bo collected as other taxes of the city of Louisville, and paid over, as collected, to the officers of said institution ....." (29)

Eventually there emerged from the library of the Polytechnic Soclety of Kentucky the Loulsville Free Public Library. The first step was changing the name to Loul sv1lle Public Library in 1901: "Therefore, be it resolved by the Executive Council of the Polytechnic Soclety of Kentucky which was created a corporation by an act of the General Assembly entitled, An Act to incorporato the Polytechnic Society of Kentucky approved April 10, 1878 namely First: That the corporate name Polytechnic soclety of Kentucky be and it is hereby changed and in lieu thereof 
the name of this corporation shall henceforth be The Louisville Public Library and by this corporate name it shall be forever known." $(30)$ The pressing need of a city-directed Iibrary continued to be felt. Correspondence with Mr. Andrew Carnegle informed the mayor, Charles F. Grainger, that Mr. Carnegie was willing to donate a large sum for a library bullding on condition that the city provide a site and appropriate annually $10 \%$ of the amount of the gift. (31)

A Kentucky Statute approved March 21, 1902, and a City Ordinance approved April 12, 1902 met the requirements set by Mr. Carnegie. (32) struction of the bullding for the newly-created municipal institution, it seemed that the city would be without a library. Despite the fact that it owned valuablo property on Fourth Avenue in addition to its 65,000 volumes

(30) Corporation Book No. 12, p. 57, Jefferson County Court, "Amended Articles of Incorporation of the Polytechnic Soclety of Kentucky," (Witnessed January 7, 1902)

(31) First Annual Report of the Board of Trustees of the Loulsville Free Public Library for the year ending August 31, 1905.

"Letter from Jas. Bertram to Mayor Charles F. Grainger," New York, January 18, 1902, p. 10.

(32) (a) Kentucky statute 2801 b

"An act providing for the establishment and maintenance of free libraries in cities of the first class (approved March 21, 1902)

(b) City Ordinance signifying and declaring the purpose and interest of the Clty of Louisvilie to ostablish and maintain a Free Public Library (approved April 12, 1902) 
and museum material, the Louisville Public Iibrary (the former Poljtechnic Society of Kentucky) was suffering reverses. There presented itself the desirability of combining this Iibrary with the city library in the process of development. Accordingly, necessary legislation was effected and a 99 year contract executed November, 1904, provided for the merging of this old library into the Louisvilie Freo Public Library. On May 5, 1905 the new library began its operations on the fifth floor of the building on Fourth Streot owned by The Loulsvilie Public Library. (33)

present structure on York Street housing the Louisville Free Public Iibrary was opened to the public. (34)

(33) First Annual Report of the Board of Trustees of the Loulsvilio Free Public Library for the year ending August $31,1905, \mathrm{p}, 11$ and 12 .

(34) Louisville Public Institutions, Vol. I

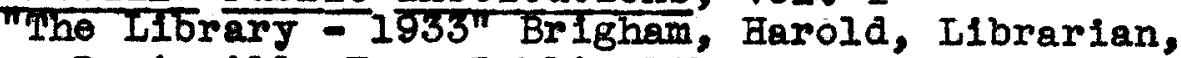
Louls vilie Freo Public Library. 
THE LYCEUM 


\section{THE LYCEUM}

In order to follow the trend of the Iyceum movement in Louisville satisfactorily, it is necessary to summarize the development of the so-celled "American Lyceum". This institution grew out of Josiah Holbrook's plan for the organization of an educational society published in American Journal of Education in October, 1826. His plan materialized in Massachusetts after the formation of the Millbury Branch, No. 1, Amerlcan Lyceum in November, 1826. After twelve or fifteon neighboring towns followed the example of Millbury, the 1dea spread throughout the United States. In May, 1828, Mr. Holbrook issued a circular outlining good programs for averago 1ycoums :

"Article I. The objects of the Iyceum are the Improvement of its members in useful knomledge, and the advancement of popular education, by introducing uniformIty and improvements in common schools, by becoming auxillary to a board of education.

"Article 2. To effect these objects, they will procure a cabinet, consisting of books, apparatus for 11lustrating the sciences, and a collection of minerals, and 
will hold meetings for discussions, dissertations, illustrating the sciences, or other exerclses which shall be thought expodient.

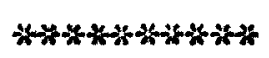

"Article 6. To raise the standard of common education, and to benefit the juvenile members of the 1yceum, a portion of the books procured shall be fitted to young minds; and teachers of schools may be permitted to use for the benefit of their pupils who are members of the lycoum, the apparatus and minerals under such restrictions as the as sociation shall prescribe." (1)

An insight into the movement at large may be gained from Josiah Holbrook's list of objectives of a 1yoerm for 1829, No. 139, published in Boston:

"1. To improve con versation by introducing worthwile topics into the daily intercourse of families, nelghbors and friends.

"2. To elevate the amusements of the community by making the weekly exercise of the Lyceum both instructive and enjoyable.

(1) Hayes, Cec1l Branner The American Lycoum", Chapter I, p. 1, 2, 3, Office of Education Bullet in - United Statos Department of the Inter10r, 1932, 10. 12. 
"3. To holp young people to save money by keoping them away from 'dancing masters, military exercises, etc.' which cost more than the jearly Lyceum foo of $\$ 2.00$.

"4. To cell into use neglected libraries and to give occasion for the establishing of now ones.

"5. To provide a seminary for teachers.

6. To encourage and assist existing academies.

"7. To increase the advantages and raise the character of existing district schools.

"8. To complle data for tom histories.

"9. To make tom maps.

"10. To make agricultural and geological sur-

reys.

"11. To begin a state collection of minerals."

In 1838 Thomas Wyse, a member of the British

Parl lament, visited the United States and upon his roturn to England wrote thus concerning the lycoum system in the Publication of the Central Society of Education Volume II: "Thousands of children, of not more then elght or ten years

(2) Noffsinger, John s.

Correspondence Schools, Lyceums, Chatauquas, p.99, p.100 
old, lmow more of geology, mineralogy, botany, statis tical facts, etc., In fine, of what concerns their daily and emotional interests and occupations, than was probably knom thirty joars ago by any fivo individuals in the United States." The foregoing statement is extravagant, but, nevertheless, it is illustrative of the Impression the 1 yceum could make on an observer.

A newspaper 1tem in March, 1831, called the attention of Loulsville citizens to the possible formation of a Lyceum. "Gentlomen desirous of forming a Lyceum in this city, will meet at the Presbyterian Church, This Evening, at 7 o'clock. At the meeting the scope and design of such an institution will be explained."

A subsequent notice revealed that "at an adjourned meoting of persons favorable to the establishment of a Lycoum in this city, hold at Mr. S. S. Goodwin's office, on Monday the 11th of April, a constitution was adopted ......... The society then adjourned to meet at

(3) Ib1d., p. 104.

(4) The Louis ville Daily Foous, March 23, 1831 
the sam place on Saturday evening, the 16th inst. at 7 o'clock. All persons friendly to the objects of the institution, are rospectrully invited to attend."

A program of lectures sponsored by the Louls7111. Lycoum during the jear 1831 included:

"Objects and ut1lity of Iyceums" delivered by A. Lovering, Esq. (6)

"Merits of the Physical Solences combined with the other brenches of knowledge" delivered by Mr. Mann But ler. (7)

\footnotetext{
"Physical scienoes compared with other great divisions of knowledge." (8)

"On the Organ of Hearing and the sound". (9)
}

(5) The Louisville Daily Focus

(6) The Louisville Da 11y Focus

(7) The Lou1svil10 Daily Focus

(8) The Loui sv1lle $\frac{\text { Daily Focus }}{\text { October }}$

(9) The Louisv111e $\frac{\text { Dail } \text { Focus }}{\text { October } 8,1831}$ 
"On the nature and utility of Chomical Sclence, with $\operatorname{som} \theta$ account of attraction" delivered by Dr. Powell. Mann Butler, the curator and librarian of the Loulsvilie Lycoum, made announcement to the patrons of the Lycoum: "Tho undersigned Iibrarian of the Loulsville Lycoum, respectfully informs its friends of his readiness to take char ge of any books, maps, natural specimens or other matters, which, they may be so liberally disposed, as to confor on an in fant institution, strugging with the public indifference for its very life. He assures them tho ir donation will be duly approciated and particularly taken care of under the orders of the Lyceum."

In the Louisville Directory of 1832 may be found an explanation of the Loulsville Lyceum. It is said to be devoted to literature and scientific subjects. Meotings are set for each Saturday evening; cost of membership - I1fo $\$ 10$, annual \$1. "This 1s, most unfortunately for the reputation of Loulsville, the only society formed professedly for literary improvement on an exten-

\section{(10) The Loulsville Daily Focus \\ (11) The Loulsville Daily Focus}


sive scale. Its objects are simply to promote popular improvement, by the diffusion of useful knowledge: 1ts means of executing these objects are, lst, witten essays; 2d, oral addresses; and 3d, discussions. A small library has been commenced by the donations of some gentlemen. Would we could enumerate its thousends of volumes, or for any other public institution, for the ifterature and innocent en joyment of our fellow citizens."

"The Louisville Lycoum, which was establishod this jear (1831) under the encouragement and with the more direct ald of some of the most intelligent and prominent citizens of the place on the 16th of September had the enterprise to send the sum of $\$ 100$ to Governor Metcalfe, at Frankfort, to be offered as a premium for a rather singular but very sensible object, described in the offer as 'the best theory of education, to be illustrated by the examination of two or more pupils who have been instructed in accordance with its principles'. The Lyceum started off well, and for a time did excellent work; but it was ovidently ahead of its time, and did not last more than

(12) Butlor, Mann

\footnotetext{
"Louisville Lyceum"

Louisv1lle Directory, 1832, p. 138
} 
a few years".

(13)

The period of greatest achievement of the National Lyceum extended from 1831 to 1839. The fact that no reports of annual meetings may be found after 1839 seems to indicate that no more meetings took place. Tow Lycoums wore the organizations in which work of selfimprovement and effective sponsoring of school improvement took place. Tom 1 yceums did not die with the national organization, but they bogan to limit thoir activity mostly to self-improvement through securing of lecturers.

$$
\text { The gear } 1840 \text { saw the establishment in Loulsville }
$$

of the so-called Frankl in Lyceum. Its primary object was the promotion of intellectual pursults. Legislative authority was given to sponsor a circulating library. The project realized littie success in its undertakings.

(13) History of The Ohio Falls Cities And Their $\frac{\text { Counties, }}{\text { Vol. I, p. }}$

(14) Hayes, Cecil Branner

"The Amer lcan Ijceum", Chapter II, p. 20 Office of Education Bullet in - Urited States Department of the Interior, 1932, 10. I2

(15) History of The Ohio Falls citios And Their Counties, 
SCIENTIFIC ADVANCEMENT GROUPS 


\section{SCIENTIFIC ADVANCEMENT GROUPS}

With the thirties and continuing intermittentiy throughout the century came marked interest among particular groups in Loulsvillo in sclence and natural phenomena. This interest is attested by the appearance of numerous societies and by selected newspeper accounts of public attendance at solentific lectures. Judging from the short 11fe of the so-called sclentific socleties, one may conclude that the met with little or no success; nevertheless, their mere formation indicates their value as "trail blazers" in the intellectual ambitions of the community. At least, they served to stimulate their patrons during a particular period.

The Medical Institute of the City of Loulsville, chartered in February, 1833, eventualiy became a school of medicine; however, amendments to the original charter had to be ffected bofore it could function adequately as an institution of learning. Although its underlying motive was the erection and maintenance of a school of medicine, it will be cited in this survey as a movement indirectly Influencing tho cultural aspects of the city. The Institute comprisod a number of leading citizens incorporated in 
1833 for the promotion and advancement of medical science in the city of Louls ville. (1) the trustees of the Louisville Marine Hospital may confide the medical department of sald hospital to the Institute; and the Mayor and Council of the city of Loulsville may confide the medical depertment of their poor-house and hospital to said Institute".

$$
\text { (2) }
$$

A group of men terming themselves the Mechanics' Institute of the city of Louisville was granted a charter by the state Legislature in 1835. The purpose set forth wes "Improvement in the mechanical arts and sciences". Again, this movement reflects the spirit of interest manifested in the "thirties". They were authorized to establish a circulating I ibrary, and "such professorships, upon any branch of mechanical knowledge or of manufactures, as they may deom fit....". (4)

(1) Acts of the General Assembly of the Commonreal th of Kentucky, I833, Chapter 244, p. 300 "An Act to establish a Medical Institute in the city of Louls vilie"

(Approved February 2, 1833)

(2) Ibid.., Section 6

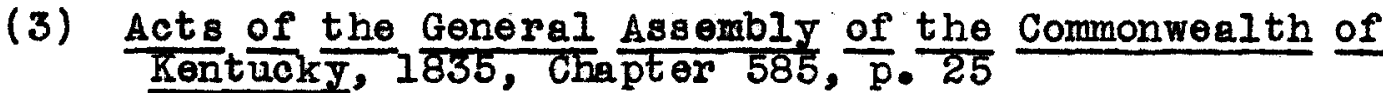
"An Act to establish a Mechanics' Institute in the City of Louisville" (Approved January 17, 1835)

(4) Ibid., Section 2 
In the preamble of the cherter of the Loulsville Medical Society granted in 1838, one finds, "that a number of individuals connected with the Louisville Medical Institute are desirous of being incorporated as a society, under the name hereunto annexed, for the purpose of cultivating, to more advantage, the science of modicine: and whereas, the usefulness of such an institution, under correct and efficient regulations, cannot be denied: and whereas, the sphere of its influence would be much extended were it recognized and sanctioned by the Legislature of this Commonwealth; and it being the wish of this body to give encouragement to literature, and especially to that part of it whose aim is the promotion of health - therefore ....".

Newspaper editorials and notices reveal the favorable disposition of the publie toward lectures of a scientific nature:

(1841) "We have nover in any place, witnessed a greater interest in sclentific lectures then is exhibited by the people of Louisville at the present time. For several winters, courses have been delivered, in different quarters of the city, with such success that arrangements have been made for

(5) Acts of the General Assembly of the Commonwealth of Kontuck ky, $1836-39$, Chapter 876, p. 251 "An Act to incorp arate the Loulsville Medical Soclety" (Approved February 16, 1838) 
recommencing them this winter. We have already announced two lectures in a scientific course to be continued during the season at the Medical Institute; and are gratified to learn that they attracted overflowing houses."

"Dr. Charles Caldwell purposes to finish, this evenIng, the remarks he has yet to offer on the effects of education in augmenting the size of the brain, and improving its qualities as the organ of the mind. Should time permit, a few other thoughts on education, conducted on phrenological principles will be submitted to the audience."

"The Monday evening lecture at the Medical Institute will be delivered this evening by Professor Yandell in the laboratory. The lecture will be demonstrative; and, as the rooms are now lighted with gas, the experiment will be seen to advantage." (8)

"Dr. Yandell will, deliver a public lecture at the Medical Institute this evening on the aurora borealis, the thunder-cloud, and other electrical phenomena. The regu-

(6) The Louisville Daily Journal, November 24, 1841

(7) The Loulsville Dally Journal, November 29, 1841

(8) The Loulsville Daily Journal, December 13, 1841 
lar scientific lecture on Monday evening will also be delivered by Dr. Yandell, and will treat of electricity as existed by the deflagrator and by the magneto-electrical machine." (9)

"Dr. Yandell will deliver a lecture this evening in the laboratory of the Medical Institute on Meteorology."

"The next scientific lecture at the Medical Institute $\nabla 11$ be delivered by Professor Yandell this evening, at half past six o'clock on hydrogen, aerostation and the oxy-hydrogen blow-pipe.

"The lectures at the Institute continue to attract the most crowded auditorios. The fact speaks well for the ability of the lecturers, and for the literary and scientific taste of the ladies and gentlemen of Louisvilie."

"Dr. Thomas Sims at the request of the Medical Soclety of Louisville will deliver a lecture in the Medical Institute this evening.

"The subject will be Phrenology as it 1s, with remarks etc. on the subject of Neurology !" (12)

(9) The Loulsv1lle Da1ly Journal, December 18, 1841

(10) The Louisville Daily Journal, January 5, 1842

(11) The Louisville Daily Journal, January 20, 1842

(12) The Loulsville Datly Journal, January 11, 1842 
"The lecture at the Medical Institute this e vening will be delivered by Dr. Bayless on the heart and circulation of the blood.

"Dr. Sims" next lecture will be delivered in the Medical Institute tomorrow evening. The subject will be Quackery in general - Neurology in particular." (13)

"Professor Yandell requests us to say that his lecture this evening on the 1lluminating gases and the miners: safety -lamp will be public." (14)

"This evening at seven o'clock Dr. Celdwell will del Iver a lecture at the Medical Inst1tute on the subject of the phrenology and philosophy of Mental sympathy and Antipathy."

"Dr. Caldwell will deliver a lecture on the 'phrenology and philosophy of the human passions'." "At seven o'clock this evening at the Medical Institute $\mathrm{Dr}$. Caldwell will deliver by request a lecture on Mesmerism." (17)

(13) The Loulsv1110 Da1ly Journal, January 17, 1842

(14) The Louisville Daily Jourmal, January 22, 1842

(15) The Loulsville Daily Journal, January 24, 1842

(16) The Louisville Daily Journal, February 17, 1842

(17) The Louisv11le Da1ly Journal, February 21, 1842 
From the foregoing the observer gets a view of an apparent display of interest stimulated through the agency of the Medical Institute. In 1851 the modical profession again manifested a desire for the promotion of its science with the formation of the Medico-Chirurgical Society of the Kentucky School of Medicine in the city of Loulsville. Its professed purpose involved "Improving the members thereof in the knowledge of modicine, and for the general advancement of medical science, through the means of essays, lectures, and debates, and such other means of investigation, consistent with laws, as the sald soclety may deem proper to adopt." (18)

The Soclety for the Advancement of Natural Sclences of Loulsville, Kentucky, was created a body politic and corporate in 1860. "Sald soclety may acquire real and personal property by gift, purchase, devise, or bequest, not to excoed in value, exclusive of any library, scientific apparatus, or collections of any kind for scientific purposes the sum of twenty-ifive thousand dollars." (19)

(18) Acts of the General Assembly of the Commonwealth of Kentucky, 1850-51, Chapter 356, p. 259

"An Act to Incorporate the Medico-Chirurgical Soclety of the Kentucky School of Medicine"

(Approved March 3, 1851)

(19) Acts of the General Assembly of the Commonwealth of Kentucky, I859-60, VoI. II, Chapter 481, p. 178 "An Act to incorporate the soclety for the advancement of Natural Sclences"

(Approved February 22, 1860) 
titled to one copy of every Geological or other scientific survey, plat, map, or table that may be hereafter published, at the expense or by the authority of the state of Kentucky, and for the dellvery of any such coples, the recelpt of the librarian shall be a sufficlent voucher." (20)

Another group of men constituted the "Loulsville Medico-Chirurgical Society" of 1869 "for the advancement of the science of medicine and the cultivation of amity and uniformity in 1ts practice." (2I) With the year 1875 came the association of men, known as the Louls ville Academy of Medicine, for "the promotion of order and harmony in the medical profession and the cultivation of medical science". (22)

In the subsequent period of years the Polytechnic Soclety of Kentucky directed the major cultural activities of the city. In 1880 a course in free popular scientific lectures illustrated by brilliant experiments was established and the society sprang into popularity increasing its membership from 137 in 1881 to 826 in 1883. (23)

Tro current

(20) Ibid. Section 2

(21) Acts of the General Assembly of the Commonwealth of Kentuck 1869, V01. II, Chapter 224\%, p. 572 "An Act for the incorporation of the Loulsvilie Modico-Chirurgical society" (Approved March 16, 1869)

(22) Incorporation Book No. 1, p. 442 Jefferson County Court

(23) Courier-Journal: Louisville, August 12, 1883 "Louis ville Ilbraries" 
newspapor editorials during the success of these lectures indicate their reception on the part of the public. "The third lecture in the (afternoon) series was given yesterdey afternoon to a large, attentive audience of ladies. The sub ject of the lecture was 'Drinking waterl' It is a source of much satisfaction to the Polytechnic Society that such great interest is manifested in these lectures, and it is hoped that this growing interest will continue to expand until all of our ladies will so arrange their time as to spend an hour once a weok in listening to Dr. Tanner's useful and pleasant explanations of scientific subjects. Next Friday afternoon Dr. Tanner will lecture on nitrogen and the atmosphere and we bespeak him a large audience." "The second lecture of this (Polytechnic Evening) popular series will be delivered by Dr. J. A. Tanner in the operaHouse to-night, and the subject will be 'Hydrogen' which will be treated in Dr. Tanner's unual masterly manner, and fully illustrated with numerous beaut iful experiments."

(24) Courler-Journal: Lou isville, December 1, 1883 "Polytechnic Afternoon Lectures"

(25) Courier-Journal: Loulsville, December 3, 1883 "Polvtechnic Popular Lectures" 
LITERARY AND MUSICAL SOCIETIES 


\section{IITERARY AND MUSICAL SOCIETIES}

There existed in Louisvilfe a number of societies that fall logically into a classification termed "Iiterary and musical". It 1 s unfortunate that the sources for this group are limited almost entirely to acts of incorporation wherein little other than objectives can be determined. The greater number of these socleties ovidently passed out of existence without exerting great influence upon the communty; one or two of them, however, developed and flourishod eventualiy bocoming leading cultural institutions in the city.

A group led by J. D. Barfield, H. A. Boles and William Owens became incorporated in 1865 under the name of the Loulsville Mutual Ifterary Benefit Society. (1) jectives are not stated in its charter. The following organization was incorporated as the "Harmony Society of Loulsville, Kentucky" through the Initiative of Levi Bamberger, William Kriegshaber, Louis

(1) Acts of the General Assembly of the Commonwealth of Kentuck Y, 1865, V01. I, Chapter 941, p. 277 (Approved February 22, 1865)

"An Act to incorporate the Lou is villo Mutual Benefit Society". 
G. Tachau, Joseph Rothchild and N. Bloom. "The purposes of the society are the establishment of a library and reading room for its members, a hall for literary discussions, and an enlightened social intercourse among its members." (2)

In 1866, T. L. Jansen, Charles J. Newman, James E. Smith, L. Jann, S. A. Garr, G. H. Allsop, C. H. Shively organized The South Jefferson Lyceum. Their objective was "mutual improvement in debate."

The same year, 1866, witnessed the establishment of the Pamphlet and Magazine Soclety of Louisville. John S. Hill, Miles Hill, W. A. Robards, S. P. Jones, R. L. Woodruff, Henry Bigfort, and their associates were the organizers of this society who proposed to establish "h l1brary and reading room for its members, a hall for literary discussions, and an enlightened social intercourse among

(2) Acts of the General Assembly of the Commonwealth of Kentucky, 1865, VoI. 2, Chapter I235, p. 138, "An Act to incorporate the Harmony Society of Louisville" (Approved March I, 1865)

(3) Acts of the General Assembly of the Commonwealth of Kentucky, 1865-66, Chapter 406, p. 332, "An Act to charter the South Jefferson Lyceum of Jefferson County" (Approved February 6, 1866) 
its members."

(4)

Daviat P. Foulds, Alexander D. Miles, James

Edmunds, Harry Bishop and Charles C. Hull were respons1ble for the creation of the Philharmonic Society of Louisville in 1867. "Sald society is created for the purposo of cultivating among its members vocal and instrumental music, by private or public entertainments and exhibitions." (5)

The Platonian Iiterary Society was founded and Incorporated in 1868. The group Included Orlando B. Wilson, James F. Buckner, Carey Peter, James F. Huber, Enoch Breeding, Henry Glove, Horace Platt. (6)

The Euterpe Society of 1880 stated as its objoct and business the provision of a "sultable building for musical, social and intelloctual status of its members, and for that purpose the Association shall have

(4) Acts of the General $\frac{\text { Assembly }}{\text { Kentucky, }} \frac{\text { of the }}{1865-66}$, Commonwealth of "An Act to incorporate the Pamphiet and Magazine Society of Loulsvilie" (Approved February 17, 1866)

(5) Acts of the General Assembly of the Commonwealth of Kentucky, 1867, Chapter 1398, p. 411. "An Act to incorporate the Philharmonic society of Louls vilie" (Approved February 15, 1867)

(6) Acts of the General Assembly of the Commonwealth of Kentucky, 1867-68, Chapter 756, p. 206

An ACt to incorporate the Platonian Literary Society of Lou1s ville" (Approved March 5, 1868) 
general power to pass such laws, rules and regulations calculated to encourage and foster the development of the musical, social and intellectual mind."

Miss Mildred J. Hill in her "History of Music In Loul sville" has listed the musical organizations that appeared in Loulsville dur ing the nineteenth century. Her list is the sole complete record of local musical $11 f \theta$. These musical organizations include:

St. Cecel1a 1822

Mozart Society 1843

Liederkranz 1848

Orpheus 1849

Musical Fund, 1857, reorganized in 1867 and 1870 Concordia Sing ing Soclety 1858

Beethoven Plano Club 1868

Philharmonic 1866

Mendelssohn 1867

Arion 1870

Mozart Quintet 1870

Moobius Orchestra 1872

La Reunion Musicale 1874

Social Maennerchor 1878

Alpenroesl1 1878

Amateur Orchestra 1879

Oratorio society 1881

Symphony 1881

Musical Club 1882

Harmon La Maennerchor 1882

Exposition Concerts 1882-86

Burck String Quartet 1887

Chatterton Club 1890

(7) Corporation Book, Number 2, p. 222

Jeffers on County Court, Jan. 22, 1880 
Saturday Night Orchestra 1890

Louisvilie Mandolin and Guitar Club 1891

Louisville Quintet Club 1891

Male Choir 1893

Orat orto Cho ir 1893

Musical Literary Club 1895

A number of the above mentioned socteties will be cited under "nationalistic cultural groups". For tho purposes of this survey, only the accomplishments of the outstanding movements $w 1$ ll bo reviewod.

The first musical society in Loulsville, the st. Cocilia, was organized in 1822. Although littlo is knom of Its achievements, 1t existed from 1822 to 1824 and was reorganized in 1835.

Professor E. W. Gunter drew togethor interested musicians in 1840 for the purpose of glving a sacred concert. The success of the concert induced the musicians to continue to work together permanently. The organization that they organized became known as the Mozart society. The exact date of its organization is not known, but it is supposed to be before 1845. The first concert of the Mozart Soclety was in St. Paul's Church and parts of Haydn's Oratorio of the "Creation" were sung. Dr. Mason, Mrs. Harry Peters,

(8) Johnston, ㅇ․ Clt., Volume II, p. 94 
and Madame Ablamowlcz sang the solo parts. The public bocame so interested in this ambitious society that the John I. Jacob family put up a hall on the northwest corner of Fourth and Jefferson Streets for the ir use and called it Mozart Hall.

With the resignation of Professor Gunter as director of the Mozart, George Brainert became its leader. Unfortunately, fire destroyed the library of the society and impaired the progress of the organization. At the close of the Civit War, in 1865, Professor Gunter colled the Mozart together for their final cancert. The event was knom as the "Peace Festival" and the society ended as it has begun with Haydn's "Creation".

The famous Liederkranz Society can be traced to a very modest beginning. A quartet composed of Messrs. Volkman, Walter, Denhard and Bernhard was formed in 1846 under the direction of a violinist named Kisten. In 1847 the quartet was reorganized under the leadership of Kremins, a piano player. In 1848 a man named Benzon came to Louisville from St. Louls to take a position on a newspaper. With Benzon came a man named Schafer who had at one time directed a quartet elub in New York. Through the paper Benzon and Schafer supported the above ment ioned quartet and called a 
meeting for the purpose of founding a singing society. The name "Liederkranz" was selected to signify that German song must be like a weath binding together the Germans of all classes. The first publ ic concert of the Liederkranz was given in 1849 .

The first National Saengerfest in the West was held in Loulsville from July 24 to July 29, 1866. The musical celebration in Loulsvilie marked the fourteonth annual "feast" of the North American Saengerbund. "Our German and American citizens, united as brethren in the great purpose of rendering the national feast now going on worthy alike of the distinguishod musical unions and of the proverblal hospltality and good taste of Kentucky's metropoIIs, worked in pleasing emulation to recelve and entertain the delegates pouring in through our gates from rail-cars and steamer $8 . "$ (10)

Singing societies represented at the "Great Fest" included delogations from:

Maenner chor, Columbus, 0. Great Western Band, Chlcago, Concordia, Chicago German 1a, Chicago

(9) Op. C1t., Vol. II, p. 86, p. 87

(10) The Louisville Joumal, July 25, 1866 


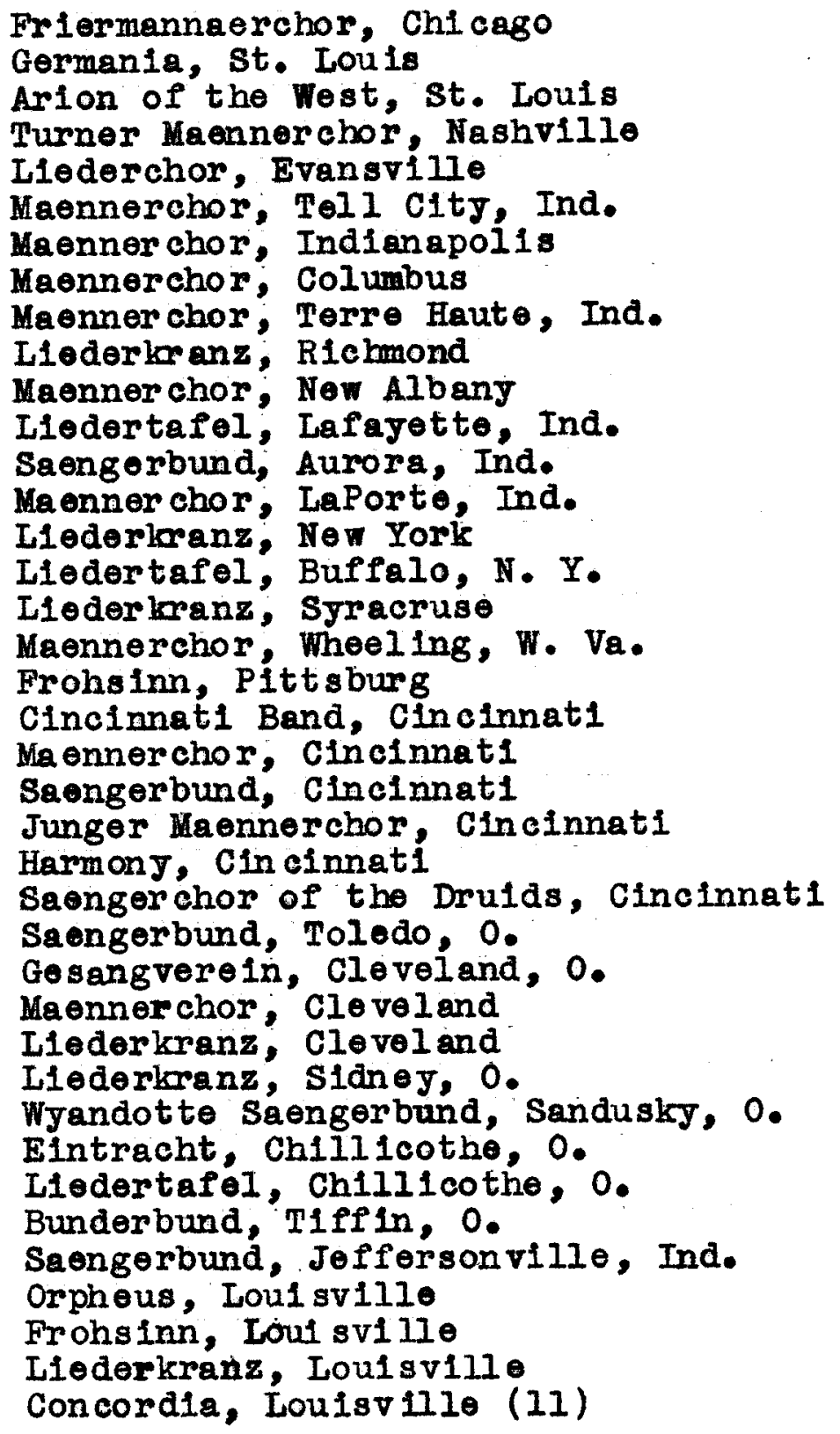

(11) The Louisville Journal, July 24, 1866 "Preparation for the Great Fest" 
The Liederkranz grew into such a successful soolety that they were able to construct a bullding suited to their needs on Market Street between First and second. The cornerstone was lald in 1872 and the building came into use in 1873 being $\mathrm{known}$ as Mus1c Hall. Upon the completion of the building, the German citizens of Louisville employed an entire opera company for two successive seasons. This bullding passed out of the hands of the Llederkranz In 1880. In 1895, the society purchased the old parsonage of St. Paul's Church on the northwest corner of Sixth and Wolnut Streets. There it erected another bullding in 1896. On Sept ember 5, 1867, John Byer and Donald Macpherson organized the Mendelssohn Club with Donald Macpherson as Prosident and C. C. Hull as Director. Mr. Macpherson, Secretary of the School Board, procured the use of rooms on the fourth floor of Center and Walnut School building. The club numbered about one hundred signers. Among the great works given by the Mendelssohn Club were Haydn's "Creation", "The Seasons", and "Imperial Mass", Handel's Mess Lah", Mendelssohn's "Forty-second and Ninety-fifth

(12) Loufsville Post, Apri1 11, 1923 Mrs. Fil $\bar{y}$ Davison "Music History 50 years ago"

(13) Johnston, p. Git., p. 88 
Psalms", "Hymn of Praise", "El1 jah" and "St. Paul", MOzart's Requiem", Beethoven's "C Mass", Verdi's "Crowned with the Tempest". The club went out of existence in 1873. (14)

La Reunion Musc1ale, organized 1874, was one of the most popular societies Loulsville has ever knom. Its first program on November 9, 1874, in the Mason ic Temple was the keynote to all their after work:

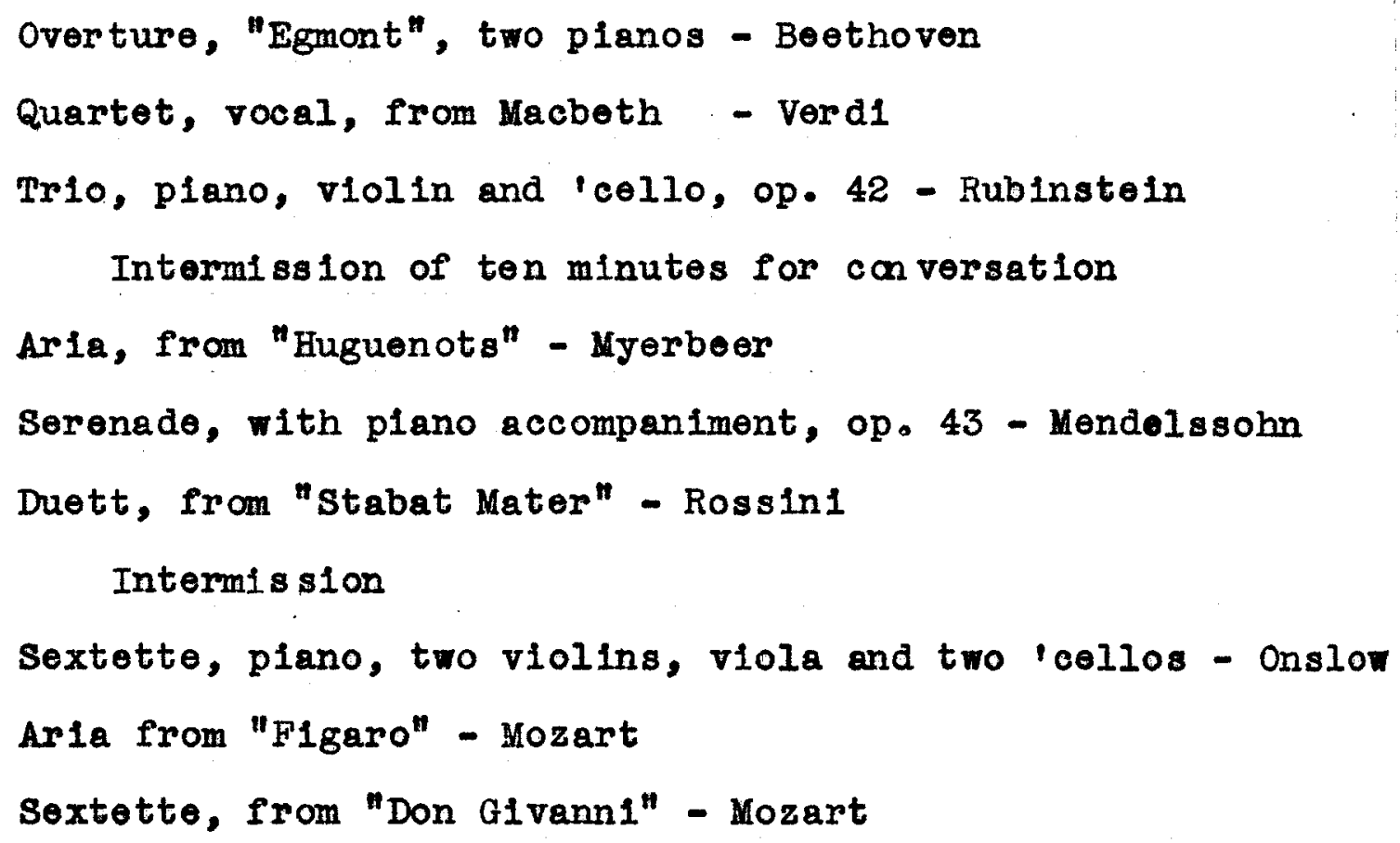

La Reunion gave these rehoarsals monthly during the season from 1874 to 1877 . (15)

In October, 1881, John Byers and Donald Macpherson called the musicians of Louisville together and a new society

(15) Johnston, Op. Cit., p. 90 
was formed called oratorio society. It was in existence seven years with Macpherson as director and William Frese as pianist. The Board of Directors were the choir leaders of the different churches of the city, and, in bringing their choirs with them into the society, the best singers were thus secured. Rehearsals were held in the chapel of the Presbyterian Church on the corner of Fourth and Chestnut streets. The works given:

1. Bach: "st. Matthow's Passion", by a double quartet

2. Handel: "Israel in Egypt", "Messiah", "Samson", "Judas Maccabaeus", Coronation Anthem" and "Dottinzein Te Doum".

3. Mendelssohn: "Elizah", "St. Paul", Hymn of Praise", "Forty-second and Ninety-fifth Psalms", and some smaller cantatas.

4. Haydn: "The Creation", "Imperial Mass", "The Seasons", entire.

5. Mozart: "The Requiem" and "Three Famous Motettes"

6. Beethoven: "Mass in $\mathrm{Cl}$, choruses from "The Mount of 011ves"

7. Gounod: "The Redemption", and several smaller woriss

8. The first rendition of Handel's "Israel in Egypt" and Gounod's "Redemption" in the West was by this society. (16)

(16) Johnston, Op. Cit., p. 90 
The Southern Exposition, 1883 to 1886, gave to the Loulsville public its greatest musical peast. During 1883 the Exposition lasted for one hundred days. Cappa's Seventh Regiment Band gave daily concerts during the first fifty days; Gilmore's Twenty-second Regiment Band provided concerts during the remaining fifty days. A chorus of 500 was directed by Mr. Donald Macpherson and Professor otto schueler. (17)

Mr. Walter Damrosch, conductor of the New York Symphony Orchestra, doscribed his stay in Loulsville during the summer sea son of 1885 and 1886 -" *** 1885 and 1886 I was invited by the Southern Exposition of Loulsvilie, Kentucky, to come there with my orchestra to play the entire summer, giving two concerts a day. I shall always look back on those two summers with delight and gratitude. I was very young and it was my first experience of a prolonged stay in a Southern city. Loulsville at that time vas a small community, but with an old civilization which manifested itself in a circle of charming people of established culture and social relations." (18)

A group of men organized the Frese Choir in 1883. "The objects and general nature of the business of said cor(17) Johnston, Op. C1t., p. 91

(18) Lou is ville Post, April 11, 1923 "Iusic History fifty Years Ago" 
poration are the formation of a male chorus for the study and practice of music and for the mutual benefit and ontertainment of its members and generaliy to make a taste for and study of music more popular." (19)

The "May Festival" under the direction of Mr. Charles E. Shackleton was one of the greatest events in the musical history of Louisville. The famous Boston Symphony Orchestra, directed by Mr. Arthur Nikisch, was engaged. A chorus of two hundred and fifty voices rendered "Stabat Mater" of Dvorak, and Mendelssohn's "El1fah". The Festival was a success artistically and financially. After the May Festival the Musical Club gave one concert at Phoenix Hill Park, after which it did not appoar in pubIic until the organization of the World's Fair Chorus in 1892. The national reputation achieved by the May Festival Chorus, 1891, caused Mr. Shackleton to be summoned to Chicago in March 1892 to attend a conference of chorus directors under the presiding of Mr. Theodore Thomas with the object of outlining plans for the appearance of large choral bodies at the World's Fair. Mr. Shackleton was requested to form a chorus to take part in the grand festival

(19) Corporation Book, Number 3, p. 13 Jefferson County Court, March 29, 1883 
to be held July, 1893.

$(20)$

The Polytechnic Society of Kentucky has been

cited in numerous instances in this survey. Its diversifled interests afforded opportunitios for cultural development in almost every line of endeavor. A newspaper article appearing in 1883 summarizes that society's contribution to the comunity. "We copy the following from the Central Method ist, and commend it to the thoughtful attention of our citizens. The Polytechnic is a peculiar Louis ville institution, and its influence on the character of Loulsville is beginning to be seen and appreciated. Its great freo library, its freo scientific lectures, its ciasses in the sciences and in art, its cholce list of newspapers and magazines present means for intelligent enjoyment and culture of which few clties can boast. The enterprise and public spirit of its managers is beyond all praise." (27)

The Louisville Literature Club organized in 1882 represents an early attempt on the pert of Louisville momen to seek cul tural improvement. The group

(20) Johnston, ㅇ․ Cit., p. 92

(21) The Courier-Journal (Louisville, Kontucky) Docemb er 11, 1883

"Our Polytechnic Abroad" 
devoted itself to the study of world literature. During the first years of its existence the members studied American 1iterature, English I1terature, and German lit(22)

erature.

In October, 1887, was founded the Monday Afternoon Club" for the encouragement of culture among women". The organization centered attention upon "I1terature, current event $s$ and art."

The Dickens Musical and Dramatic Club of 1886 stipulated that its membership be Iimited to forty- seventeen 1 adies and twenty-three gentlemen. Its object was "to develop and direct the talents of each individual member in such a way as to be beneficial to the club and the club's friends." (24)

The Woman's Club of Ioulsville organized a few years earlier, 1890, became incorporated in 1895. The cherter gives the object of the association as "mutual

(22) The Louisville Times (Loulsville, Kentucky) December 31, 1909 Randolph, Eelen Murray - "The Louisville Woman. Her Club Activities and the Splendid Things she is Accomplishing * "

(23) Ib1d.

(24) Constitution and By-Laws of the Dickens Musical and Dramat $1 \mathrm{c} C \mathrm{Cub}$ Touisvilie, Kentucky 
sympathy and counsel and united effort to further reform and improvement in the community in which we I1ve." Th1s particular organization has experienced success in becoming a vital influence in providing facilitios for cultural improvement in the community. Thirty-olght women, influenced and stimulated by Mrs. B. F. Averg's enthusiasm, formed the nucleus of this organization meeting for the first time in March, 1890. Mrs. Patty B. Semple was the first President of the Club. Early meetings were held in members' homes, later in Hampton Gymnasium, the Galt House, College Street Chapel, Elk's Hall, and finally in the Woman's Clubhouse, formally opened October 15,1902 .

During the nineties the Club sponsored the followIng:

1892 to 1893 Lectures by Dr. John Fiske and Mr. James Lane Allen. Froe exhibition of impressionist pictures. 1893 to 1894 Lecture by Mrs. Charles M. Kurtz Reading by Mrs. John Fox

1894 to 1895 Lectures by Mr. Walter Damrosch and Rabbi Moses 1895 to 1896 Series of lectures by Mr. Walter Damrosch

(25) Corporation Book, Number 9, p. 197 August 27, 1895 
1896 to 1897 Lectures by Mr. Hamilton W. Mabie and Mr. Froder1c Root.

Concerts by Mr. Plunkett Green and

Miss Villa Whitey White. (26)

The success of this organization may be estimated though the following citation: "The Woman's Club has exercised such a powerful influence for good in the community, has inaugurated so many reforms, has launched so many philanthropies, has brought such a number of the most famous musicians, lecturers and authors to Loulsville, has given art exhibits unsurpassed by any similar club in the country, has entertained so many of the nation's most distinguished men and women, fostered such far-reaching legislative reforms that the tribute paid it by the representative of the Carnegie Institute for Scientific Research that ift is the greatest eth1cal influence for public sentiment in the state' is easily understood". (27)

(26) Yearbook of the Woman's Club of Loulsville, 1906,

(27) Louis ville Library Collection

Institution Series, Vol. I, p. 345, p. 346

Quoting The Louisvil le Times (Louls ville, Kentucky)

December. 31, 1909 
NATIONALISTIC CULPURAL GROUPS 
NATIONALISTIC CULTURAL GROUPS

Through the formation of their various socletios imigrants affected indirectly the cultural development of Louisvilie in the nineteenth century. A number of these groups have continued to exist to the present time successfully preserving among their members a nationalist ic consclousness. Their primary object was to help the individual become adjusted to the American community. These groups, too, were agencies of transmitting European culture to the American scene. Despite the fact that many of these groups were organized purely for benevolent and social purposes, they evidently influenced indirectly the cultural development of the participants. Swiss, German and Irish organizations appear in the avallable rocords. Census reports for the second half of the century show the number of Louisville's forelgn-born population cit ed in this study:

I. 1850

Aggregate population of Loulsvillo 43,194 German foreign-born ........... 7,352 Irish for $\theta 1 \mathrm{gn}-$ born $\ldots \ldots \ldots \ldots \ldots$ 3,105

(1) Statistical View of $\frac{\text { The United }}{\text { Compendium }} \frac{\text { States }}{\text { Of }}$ - Being a Washington: A.O.P. Nicholson, Public Printer, 1854 p. 365, p. 369 
(2)

II. 1860

Aggregate population of Louisville

German forelgn-born ............

Ir1sh foreign-born ............. (3)

III. 1870

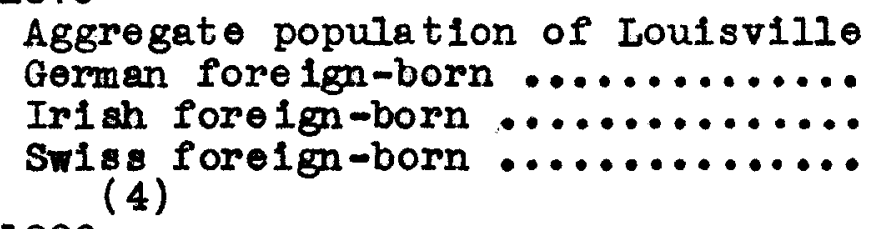

IV. 1880

$$
\text { (4) }
$$

Aggregate population of Loulsville

German forelgn-born .............

Ir1sh foreign-born .............

swiss foreign-born .............

V. 1890 (5)

68,033
13,374
6,653

100,753

14,380

7,626

560

123,758

13,463

6,474

440

Aggregate population of Loulsville

German fore 1gn-born ............

Irish fore 1en-born .............

swiss foreign-born ............. (6)

VI. 1900

Aggregate population of Loulsville

German for 1 ign-born .............

Irish foreign-born .............

swiss forelgn-born .............

161,129

14,094

5,263

581

204,731

12,383

4,198

717

(2) The Eighth Census Statist1cs of The United States in 1860 Washington: Government Print ing offlce 1866 p. XVIII, p. IVIII

(3) Ninth Census - Volume I

The Statistics of The Population of The United States Washington: Government Printing ofice, 1872

$$
\text { p. } 386, \text { p.389, p. } 390, \text { p. } 391
$$

(4) Statistics of The Population of The United States At the Tenth Census 1880

Washington: Government Printing office, 1883

$$
\text { p. } 538, \text { p. } 539 \text {, p. } 541
$$

(5) Report on Population of The United States At The Eleventh Census, I890 Part I

Washington, D. C.: Government Printing office 1895 p. 670, p. 671, p. 672, p. 704

(6) Census Reports - Twolfth Census of The United States, 1900 Washington: $U$. S. Census offIc $\theta_{1}$ I901

p. 453 , p. 797, p. 798 , p. 799 
The Swiss element in the population of Loulsville has been active in maintaining their nationalistic societies. The first Swiss Society in Louisville, the Gruet II Benevolent Soclety, was established May 16, 1850, under the name of "The swiss society". Since that time the Helvetia, Schweltzer Bund, Alpenroesil, Edelweiss, Swiss Charity Society, Swiss American Club, Swiss-American Home Association, and the Yodel Club have been organized and all are active and prosperous. The latest 18 the United Swiss Society which is made up of five members from each of the other nine swiss societies in the city. (7)

In 1871 a group of leading Swiss-American citizens, William GeIpel, W. Hock, J. C. Bamberger, Edward Ka1ser, J. Kipfer, J. Hunziker, Con Schöttlein, J. Burge, and Charles Mueller, formed an association for the purpose of social refinement. Objectives were set up of "general improvement in strengthening the ties of friendship already existing between the swiss residing in the state of Kentucky and cities of New Albany and Jeffersonville, Indiana, and of honorably representing the ir nationality of encouraging the emigration to the state of Kentucky and to cement more closely the bonds of union that should ever exist among

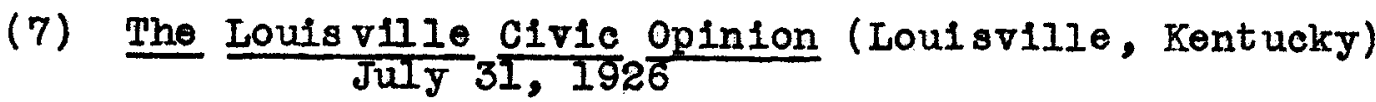


Swiss under the name of Helretia Society and said assoclation desires corporate power that it may carry on Its business as a body and own and hold property for its uses as a society." (8) president of the society in 1926, his group has furthered and encouraged the immigration of Swiss to Kentucky. In the course of Its existence it has arranged many activitios, chief among them the successful presentation of "Williem Tell" and "Bluemlis Alp". (9) Among the Germans one finds that music was evidently the cultural interest that had the greatest appeal in drawing individuals together for refinement and improvement. One of Louisville's oldest male chorus groups that has the distinction of being one of the oldest singing socleties of its kind in the entire South was organized on February 12, 1848, on the ground floor of a church that stood on the southwest corner of Fifth and Walnut Streets. It flourished as the Louisville Liederkranz and came to be one of the dominant

(8) Book of Incorporation No. 1, p. 48, Jefferson County Court.

"Act of Incorporation of Helvetia Society of Kontucky"

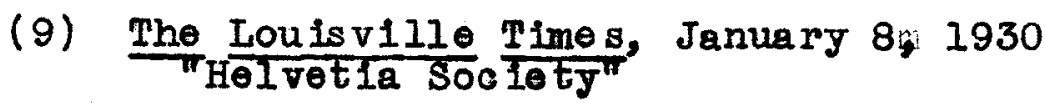


(10)

forces in musical circles in the city.

In 1858 the Lieder Kranz Soclety of the city of Louisville was granted a charter by the General Assembly of Kentucky; its objects were given as the cultivation of skill and diffusion of taste in (II)

music.

It endeavored to effect "the cultivation of skill and diffusion of Taste in music and the cultivation of social intercourse among its members."

Another group of German singers, the Concordia singing Society, boasts of a continuous record since December 28, 1855. It has the distinction of being the only Catholic singing society of its kind and the oldest German Catholic singing society in the South. This group participates in the North American Saenger Bund.

(10) The Herald-Post (Louisville, Kentucky) February 1I, 1933

(11) Acts of the General Assembly of the Commonwealth of Kentucky, 1857-58, Vo1. I and 2 , Chapter 797, p. 357 "An Act to incorporate the Lieder Kranz Society, of the City of Louisvilie (Approved February 17, 1858)

(12) Book of Incorporation No. 1, p. 96, Jefferson County Court "An Act of Incorporation of Liederkranz Soclety" (Novemb er 6, 1871)

(13) The Courler-Journal (Loulsville, Kentucky) December 29, 1925 
An act of incorporation approved in 1870 explained that there was formed in the city of Louisville an assoclation called the "Loulsville Saengerbund". This group Iisted as Jullus Dorn, G. Baurman, G. S. Schuhmenn, N. Bloom, M. Byur, J. Von Borries, Theodore Schwartz, A. Brandeis, J. J. Flscher, and F. Reidhar, professod to wish to bulld a hall to be called "Germania" with a public library, reading and lecture rooms. The sald corporation shall have power to keep, manage, and conduct an 'Academy of Mus1c, Ilbrary, and Lecture Rooms', in the city of Loulsville; to employ agents, clerks, and servants, and to provide for musical and other entertainments. It may erect and build all storehouses and other buildings, In connection with the Academy, as it may deem expedient for the successful keeping and conducting of said Academy of Music ......."

The Teut on ia Maennerchor of Louisville originating in 1871 desired to cultivate musical en joyments and friendship. It included as its founders I. E. Eck-

(14) Acts of the General Assembly of the Commonwealth of Kontuck 1869-70, Vol. I, Chapter 24, p. 29 "Preamble" (Approved January 7, 1870)

(15) Ib1d., Section 2 
stenkemper, L. Daeuble, P. Eltel, R. Mansvield, V. Ste in, Charles Armbrust er and B. Erb. (16)

The Louisvill e Turngemeinde represents an interesting unit of the international organization known as the Turnverein, a German institution founded in the early part of the nineteenth century for the purpose of furthering physical education. The idea of the original organization was carried to the United States by German settlers who later extended their objectives to include the discussion of intellectual, political, social and religious ideas. (17)

The father of the "Turnverein" was Frederick Ludwig Jahn, a German pedagogue and patriot (1778-1852) born in Lanz. He became knom to his adherents as Turnvater ("Father of Gymastics"). He studied thoology and philology from 1796 to 1802 at Halle, Gottingen and Greifswald. After Jena he joined the Prussian army. In 1809 he went to Berlin, where he became a teacher at the Gymnasium Zum Grauen as well as at the Plamann School.

(16) Incorporation Book, No. 1, p. 58, Jefferson County Court, "An Act to incorporate the Teutonia Maennerchor of Louisvilie Approved May 20, 1871)

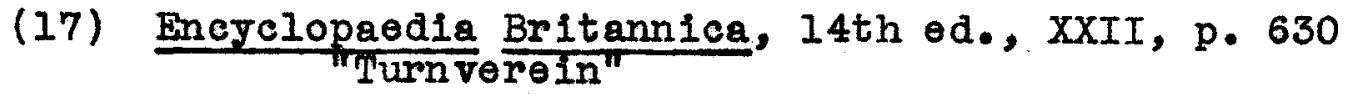


Bróoding upon the humiliation of his native land by Napoleon, he conceived the ldea of restoring the morale of his countrymen by the development of their physical and moral powers through the practice of gymnastics. The first Turnplatz, or open-alr gymaslum, was opened by him at Berl in in 1811, the joung gymnasts boing taught to regard themselves as members of a kind of guild for the emancipation of their fatherland. In 1813 he took an active part at Breslau in the formation of the famous corps of "Lützon," a battalion which he commanded, though during the same period he was often emplojed in secret service. After the war he returned to Berlin, where he was appointed state teacher of gymnastics. As such he was a leader in the formation of ten student Burschenschaften (patriotic fraternitios) in Jena. (18)

A man of democratic nature, rugged, honest, eccentric and outspoken, Jahn often came into collision with the reactionary spirit of the time, and in 1819 the Turnplatz was closed and Jahn was arrested. He was detained at the fortress of Kollberg until 1824, and sentenced to imprisonment for two years: but his sentence 
was reversed in 1825, though he was forbidden to Iive within ten miles of Berlin. He sottled at Frejburg on the Unstrut, where he remained until his death (October 15, 1852), with the exception of a short period in 1828, when he was exiled to colleda on a charge of sedition. In 1840 he was decorated by the Prussian government with the Iron Cross for bravery in the wars aga inst Napoleon. In the spring of 1848 he was elocted by the district of Naumburg to the German national parliament. (19)

The first (Turnverein) socleties in the United States wero formed in Philadolphia and Cincinnat1 in 1848 by German refugees ....... (20) It is reported that the Loulsville Turngemeinde ras established on september 2 , 1850, with the principal object of cultivating both the body and mind of its members. During the first eleven years of 1ts existence the society is sald to have prospered and flourlshed as one of the leading societies in the city.

(19) Ib1d., XII, p. 867

(20) The Wor Id Book Encyclopedia, Vol. 16, p. 7321

(2I) The Louis ville Post (Louisville, Kentucky) 
In an address commemorating the seventythird anniversary of the Loulsville Turner organization, Alfred Seligman tells the history and aims of the society, thus Iy:

"The history of the Turner Socletios In the country of its origin and as transplanted to the United States, is the story of brave, plain men and wamen who love liberty, who strive honestly to do their work in the world, who seek to live lives of service, to be of open minds in matters of faith and conscientiously to support the cause of education of the mind and of the body, and in every aspect of life to bo good and law abiding citizens of the country in which they $I 1$ ve and have cast the ir fortunes.

"I know of no higher or nobler purpose to be pursued by men and ramen.

"The story of Freder lck Ludvig Jahn, its founder, and of Beck, Falien and Lleber, his ardent supporters, often has been written and is a familiar story.

"Turner ism had its beginning in saxony in the darkest hours of Napoleon's oppression. Patriot ism in Gormany was dead. Sycophancy alone thrired. Jahn declared that the hope of his distracted people lay in the proper educetion of the young, based on the elements of learning and developed through its higher aspects and couplod with a rational physical training. It was to be a substitute for militarism and absolutism which the Turngemeindes consistently have opposed.

"The Idea met an almost instant response. His school or gymnasium flourished. It was like the breath of new 11fe. The followers of Jahn entered fuliy in the ir part of the bur- 
den. Germany was freed of the Napoleonic joke.

"After the restoration, the Turner socleties renewed their political activity, declaring for a more democratic form of government, enlarging political rights for the masses, and freedom of thought and conscience for all al ike.

"The movement was not revolutionary but stabilizing and constructive. It was much in the spirit of our ow struggle in America, wich established order with liberty.

"Autocracy at home found Turner 1sm an obstacle to tyranny and the King of Prussia sought to crush 1t. Jahn first suffered imprisonment and later was banishod. He died in 1852, having the happiness to see his idea recognized by the Government itself.

"Beginning with 1842 the movement grew stronger and was a powerful factor in the German Revolution of 1848. The sad story of that struggle is mown. Reaction carried the day. From its bitter disiliusions and dreadful aftermath, many leaders and disciples fled to the hospitable shores of Amerlca.

"Our history was enriched, our community strengthened and our prosper 1ty enhanced by the acquisition as citizens of these brave men and women who thus became bone of our bone, flosh of our flesh, sinew of our sinew.

"Among the earliest Turners who came to the United states were Dr. Karl Beck, who in 1894 opened a school in Massachusetts and later became professor at Harvard: Dr. Karl E. Fallen, who came in about 1830, and who likewise taught at Harvard, establi shod a gymnasium in Boston and became a preacher in the Unitarian Church; Franz Liober, who came to the United States in 1827, taught gymastics and was the oditor and 
publisher of the Incyclopedia Americana and a recognized authority on International Law. Other notables among the refugees were Carl Schurz, Franz SIgel and Frederlok Hecker, who in war and peaco vindicated the highest ideals of citizenship and lojalty.

"As every student of history knows, the voluntary immigrant of every period, and from every clime, under normal conditions, generally has represented the best of his native land.

"The daring to leave old associations, to break old ties and to seek and to endure adventure to secure freedom of conscience, and the opportunitios to improve and advance themselves and their children, is of itself the result of a process of selection, wich brings out the stronger and the braver. The inefficient, the indifferent and the indolent, unless driven by circumstances stronger than themselves, do not emigrate. It requires a spark of divine courage, a spirit of fine adventure, $a$ boldness and foresight to tear up life by the roots, to face the perils of the sea, to learn a strange tongue and alien laws and customs, to blaze the path through the forest, to make the garden in the desert, to soek new fortunes, in an unknown and far away world.

"Naturaliy, following this tide of home seokers in our 1 and, Turngemeindes or Turner Socleties were organized in various american cities. That in Loulsville was organized seventy-three years ago and was typical of all the rest. It has continued to exist honorabiy and successfully.

"My earliest recollections are of the.members of this society whom I knew in my boyhood and early manhood. They constituted a body of fine upstanding men and women, given to good works and kindiy deeds, living clean, simple lives and constituting a source of wealth and 
prosperity and well being for the entire community. The same characteristics and traditions exist to this day.

"Among them I formed friendships and affections which happily have endured to this day. It would be invidious to select names for special mention from among that band but their influence was all for good. But this society was something more than a mere gossip for pleasant assoclation.

"The Turngemeinde was the debating society wherein were discussed the questions of the day and formation of forward looking pollcies, many of which later recelved a wider advocacj.

"In the struggle for the abolition of slavery, the Turngemeinde of America pleyed a conspicuous part. Their halls were the meeting place of those opposed to slavery. It is said that Wendell Phililps himself on one occasion unable to obtain a church or other place in which to speak, used the Turner Hall of Boston and the members of the society constituted a personal guard to secure his safety. Naturaliy it folIowed that the Turners were almost unanimousiy for Mr. Lincoln for the Presidency and in the War of secession were practically united for the Union Cause. They were not only for emancipation but for the Union, and in this war poured out their blood like water under generals and captains Iike Schurz, Hecker, sigel, Willich, and many others.

"They ever have been staunch defonders of our public schools and the right of free speech and a froe press.

"A clause in the Soclety's declaration of principles, reads:

'We, the members of this union, believe in the United States of America as a democracy in a republic established upon the principles of freedom, equality, justice and humenity, and 
recognize in the harmonious education of body and mind one of the most important prerequisites for preserving and perfecting this democracy.'

"Thus, it has been that the Turnvereins of America always have stood for the freedom of the individual, for the freeing of the human mind from the forces of bigotry and superstition and for the development of rational education, physical and mental in order to qualify its youth for citizenship in tho Republic to which they have boen and are so doeply devoted.

"As one writer has sald, 'strongly individuallstic, the Turner desires a republic in which every citizen is truly sovereign, in which the welfare of al stands higher than the advantage of individuals.'

"It follows from these principles in the matter of polftical, economics and social progress, the Turngeme indes have stood and stand against radical revolutionary programes of every kind

"Some of the political tenets of the American Turner Societies announced as early as 1870 and all as early as 1878 were for:

First - The secret ballot
Second - Initiative and referendum
Third - Direct election of United States
Senators
Fourth - Women's suffrage
"Some of these advanced social and economic
ies promulgated by these newcomers forty years
of the times, have come to be accepted gen-
y.

"It is not proper here to go into an analysis of the ir views and I shall not do so, but it is sufficient to say that the spirit and ideas which formed the foundation of social and moral beliefs of this group were vigorous and free from bigotry; 
were founded upon that deep and growing sense of human fellowship, which since has expressed itself in the widespread social unrest seeking the correction of social and economic evils in the world, and for which in this age has been so much labor and sacrifice.

"They insisted upon no formal religion. They upheld the private virtues of sincerity, truthfulness, industry which ever adorn personal character. They believed that in relation to his fellowmen, the individual is required to be righteous, to uphold justice, to be champions of the poor and the oppressed, ever ready to wipe the tear from off the cheok of sorrow, to strike the shackles from the enslaved, clothe the naked, foed the hungry, to be a father to the fatherless. They cared nothing 'to preach religion handsome and out of the wet.'

"It would have surprised them most of all to be told that they were practicing the essence of all religions, laid down by the prophet of old.........

"They believed and taught that 11 fo had a solemn purpose, that its tolis and its services, its duties and tasks, were to be done with a whole heart, a whole mind and $a$ whole soul, and in obedience to a fundamental obligation from which no man, high or lor, is exempt.

"They belleved and taught that life's achievements were founded upon character, and that without incerity and character, iffe was trivial and superficlal, and noble achlevements impossible.

"And all these things which were true of the members of the society years ago continue to be true to this day and the same principles saturate the heart and influence the mind and conduct of those who are now the members and supporters of the Loulsville Turngemeinde." (22)

(22) The Courier-Journal (Loulsville, Kentucky) september 30, 1923

"Turners Mark 73d Anniversary" 
Although the establishment of the Louisville organization of Turners is set at the date, September 2 , 1850 , the society did not become incorporated unt1l 1893. The Articles of Incorporation read that "Andrew Peklenk, Fred Obermiller, Robert Winkler; Ed. Ornstein, Edmund Groeschel, Herman Rleke, F. Keidel, Henry Huening and Joseph Wintergerst, have associated themsel ves together and become incorporated under the corporate name of the 'Turn-Verein Vorwaerts' .... The purposes of sald corporation are the strengthening and developing of a love of gymnastics, and to provide suitable and proper means for the gratification of the same, the promotion of intellectuaf recreation and literary education of its members, and the elevation and improvement of the powers and capacities of the physical men, and the higher facultios of the mind."

Another group that has helped to preserve a

nationalistic consciousness by playing a prominent part in the Ifves of the German element of Louisvilie is the Swabian Society of Schwäbischer Unterstützungs - Verein composed of individuals from Wirtemburg, Germany. Organized primarily

(23) Corporation Book, No. 8, p. 293, Jefferson County Court

"Articles of Incorporation of the Turn-Verein Vorwaerts" March 7, 1893 
for benevolent purposes, the society has become known for its social activities where in members have participated in plays and dances in costumes native to their father land. (24)

was conceived in 1879; the first meeting was held on August 24, 1881, and the organization was incorporated on April 25, 1882 through the initiative of William Maier, Gottlieb Dreher, William Wagner, Christ Kuhn, Conrad Binder, and Albert Pfeiffer. (25)

1scher sängerbund was organized, but it disbanded after a short existence. (26)

The Articles of Incorporation of the celtic Ilterary Association bear witness of Irish activities along cultural lines. In $1873 \mathrm{~mm}$. H. Graham, Peter J.

(24) Kurze Chronik über Entstehung des Sohwäbischer Unterstutzungs - Verein " Publication of the Schwabischer UnterstutzungsVerein, Louisville, Kentucky, 1895

(25) Corporation Book, No. 2, p. 485 Jeffersof County Court

"Articles of Incorporation of the Schwabischer Unter stut zungs-Ver ein" Apr11 25, 1882 .

(26) Kurze Chronik uber Entstehung des Schwäbischer Unterstutzungs-Verein Publication of the Schwabischer UnterstutzungsVerein, Louisville, Kentucky, 1895 
Dowling, M. J. Tierney, Daniel Fitzgibbon, James McKeag, Daniel E. Donoval, John Kelly, James J. Boyle, Robert M11ler and Matthew 0 . Dougherty were granted a charter to establish the Celtic Iiterary Association of Louls(27) ville.

The object of this association was to be the erection of a suitable building or buildings for a Lyceum, Library, lecture, and meeting rooms to be devoted to the "social mind" and intellectual elevetion of its members and the general public. The organization hoped to encourage and foster the development of the Irish character throughout the world. (28)

to be Iimited to persons of Irish birth or lineage.

It will be noted that no mention has been made of activities of Italian immigrants in Louisvilie, Search disclosed that the firgt Italian-American club was organized by prominent citizens of Italian nativity on November 4 , 1906. The purpose of the organization as set forth in its constitution is for "the good and welfare of its members and all of Italian birth or descent residing here and

(27) Corporation Book, No. 1, p. 261, Jefferson County Court "Act of Incorporation of the celt ic Literary Assoc Lation" June 21, 1873

(28) Ibid., Section 2

(29) Ibid., Section 4 
for the improvement intellectually of local citizens of Italian birth and descent, to encourage social and brotherly intercourse and to disseminate knowledge that would lead to botter understanding between those of Italian descent and those citizens who descend from other nationalities; to aid Italians here to become good and useful citizens of the United States."

(30) The Louisville Herald-Post, (Louisville, Kentucky) Fobruary 13, 1927

"The Italisn-Amer Ican Club" 
HISTORICAL SOCIETIES 


\section{HISTORICAL SOCIEITES}

Records show that three historical societies were established in Loulsille during the nineteenth century. Unfortunately, the first two organizations that appeared were short-lived and passed out of existence without achieving their objectives. They are important, despite their fallure to realize success, in Indicating the interest in historlcal matters. They. too, may be regarded as forerunners of the third organization that flourished, developed, and ultimately enlarged Its scope and facilitios to become the dominant society of its kind in the city and the state. The first organization in this group lmown as the Kentucky Historical Society came into being in 1838. It designated Loulsville as its headquarters and location of its library and cabinet. " constitution and by-laws were adopted March 29, 1838, and the society went hopefully into operation. Hon. John Rowan was President; Hon. George M. Bibb and Henry Bibb, vice-presidents; D. C. Banks, recording secretary; Edward Jarvis, corresponding secretary and librarian. It was in existence 
for a number of jears, but long since became extinct, and its collections were dispersed".

The Act to Incorporate the Kentucky Historical

Society, approved February 16, 1838, reads in part, as f0110ws:

"Whereas, the collection and preservation of the antiquities of our country, and of memorials and documents serving to illustrate its history and institutions, or to mark the progress of society, arts, and letters, in the United States, have a tendency to enlarge the sphere of human knowledge, ald the advancement of sclence, to perpetuate the history of moral and political ovents, and to improve and interest posterity - therefore,

"Soction 1. Be it enacted by the General Assembly of the Commonwealth of Kentucky: That John Rowan, George M. Bibb, Harry Pirtlo, George D. Prentice, Reverend James F. Clarke, Reverend Benjamin O. Peers, Simeon S. Goodwin, James Brown and Leonard Bl1ss, Jr., and Humphrey Marshall, Sr., Wilkins Tannehill, and Edward Jarvis, $M$. D. and such others as may associate with them for the purposes aforesaid, be and they are hereby constituted a society, and body poIitic and corporate, in law, by the name and style of the Kentucky Historical Society; ......... $(2)$

(1) History of The Ohio $\frac{\mathrm{Falls}}{289}$ Cities And Their Count1es,

(2) Acts of the General Assembly of the Commonwealth of "An Act to Incorporate the Kentucky Historical Society" (Approved February 16, 1838) 
According to the remarks of Colonel Reuben T. Durrett dealing with the Kentucky Historical Society, one finds that it "was not of long duration, but it served as a connecting link between the first librarles in our city and those which succerded, and thus reserved for posterity some valuable relics of the past. It took into its charge the letter written by General George Rogers Clark to his friend, the Hon. George Mason, of Gunston Hall, Virginia, and saved it from the destruction which deprived posterity of the journal of Captain Thomas Bullitt, and other important records of our early times. This letter is dated Falls of the Ohio, November 19, 1779, and gives an account of the capture of the Brit1sh posts of Kaskaskia, Cahokia, and Vincennes in 1778, which did more to save our forefathers from the tomahawk and scalping knife of the savages than any other acts durIng the Indian Wars upon our border. That this manuscript might not perish as others had done it was sent to Robert Clarke, of Cincinnat1, who published it in a book of one hundred and nineteen pages in 1869, and thus placed it bejong the possibility of loss to the world. If the Kentucky Historical Society had done nothing but preserve this manuscript, its existence would not have been in vain; but it did more, and preserved a number of valuable books, 
which now appear in other libraries, and which can no longer be purchased".

(3)

Not until the establishment of the Polytechnic Society of Kentucky in 1876 was another historical assoclation formed, so far as is known. The by-laws of the Polytechnic society provided for the establishment of departments for the pursuit of speclalized knowledge. Article VII of the society's By-laws authorizes the establishment of "Academies" in the following manner:

"Section 1. In order to further the object of the Polytechnic Society, and promote the cultivation of knowledge in History, Language, Sciences, Art, Philosophy, and Technology, any five or more members of the soclety may assoclate in the formation of an Acadomy for the cultivation of any branch of useful knowledge approved by the Executive Counc1l.

"Section 2. Each Acedemy so formed may prescribe its own rules of order and conditions of membership, provided no one shall be admitted to membership in any Academy who is not a member of the Polytechnic society of Kentucky•

"Section 3. Each Academy hall make a full report of its organization to the Executive councll, including coples of all by-laws and other standing rules, and shall also make an annual report of 1 ts proceedings at, or before the March meeting of the Council". (4)

(3) Quotation from Colonel Reuben T. Durrett relating to the Kentucky Historical society of 1838 in History of The Ohio Falls Cities And Their Counties Vo1. $1, p-422$.

(4) Pamphlet: Act of Incorporation and By-Laws of The Polytechnic Society of Kentucky, Article VII of By-Laws. 
An Academy of History was accordingly organized in 1883. A group of men assembled on July 25, 1883, in the Council rooms of the Polytechnic Society of Kentucky to organize a "Loan Exhibition" of objects 11lustrat ing Kentucky History for the Southern Exposition then being held in Louisville. A temporary organization was effected with R. T. Durrett as chaiman and Thomas Speed as secretary. A proposal was mado for the formation of an Historical Acadeny of the Polytechnic Society of Kentucky. A committeo was appointed to draw up a constitution and by-laws. (5)

Beginning in 1883 and extending through 1886 there was held in Loulsville an exposition of Southern products and industries coupled with improved machinery and appliances of the North. It was the successor of the Atlanta Exposition of 1881. In order to bring the project to Louisvilie citizens of Louisvilie, New Albany and Jeffersonvillo subscribed $\$ 250,000$. The exposition was described as the most magnificent demonstration that had occurred in America with the exception of the Centen-

(5) Minutes of Meeting of Academy of History of the Polytechnic Society of Kentucky, July 25, 1883 (Office of clerk of United States District court of Western District of Kentucky) 
nial Exposition of 1876.

(6)

The Exposition grounds were located in an area adjoining Central Park. Buildings housing the various demonstrations were classified under the following headings: I. Natural Products; II. Machinery; III. Manufacturers; IV. Transportation; V. Music, Literature and Art. (7)

The newly formed Academy of History was concerned with producing a display of Kentucky relics at the Southern Exposition. A news item appearing in the Courier-Journal on Sunday, July 29, 1883, referring to the organization of the Academy for the Preservation of the Historic Records of Kentucky says:

"The meeting was not a large one, but consisted of gentiemen who take an interest In historic subjects, and the spirit manifested on the occasion was indicative of that kind of earnestness which insures the success of such undertakings.

"There is no part of our country whose historic field is more diversifiod and inter-

(6) The Industrial Revier. August 1, 1883 Published by John W. Ryclomen

"The Southern Exposition" - D. E. Sullivan, p. 1.

(7) Visitors' Guide To The Southern Exposition At Louis ville, Kentucky PubIished by LouIsville Daliy comercial Loulsvilie, Kentucky, 1883, p. 43 
esting than that of Kentucky. Here began that contest between the white man and the red which look to dominion over the vast region stretching from the Allegheny Mountains to the Pacific ocean. Here civilization first began to follow the footsteps of the ploneer as in his westward march he crossed the Ohio, passed the Mississippl, climbed over the Rocky Mountains, and finally arrested his steps on the shores of the Pacific. We have a history, which anterior to our own, records the deeds of Fngland, France and Spain for dominion here; and going beyond these mighty powers, stretches over the centuries of aboriginal tribes unt1l it is lost in the shadows of the mounds whose origin none may tell.

"It is the object of the academy just organized to preserve such records of Kentucky's past history as may jet be within its reach while gathering those of the present and future. The rude implements of the mound bullder and the Indian will have their place in this collection, as well as the book, the pamphlet and the paper of the Englishman, the Spanlard and the Frenchman. Nor will our collection be complete until we glean from some adjacent states, for the history of Virginia is our own, while that of Ohio, Indiana, Illinols and tho other glorious republics carved out of the territory were by our clark as our kindred.

"It is the intention of the academy while gathering historic rorks for the use of it $\mathrm{s}$ members to give strangers the opportunity to see the curiosities of the collection. The association is already in possession of some of the wonders of history, such as early printed books, pamphlets, maps, papers, etc., and othersare promised. These will be exhibited to strangers during the Exposition, and it is the hope to enlarge the collection by the addition of such curiosities as may bo lent or given for the occasion. Arrangements will be made with express companies to bring and return freo of cost to the owners such books, papers, relles, otc. as may be worthy of exhibition in a historic coliec- 
tion. A comittee was appointed at the meeting yesterday who will issue a circular specifying the things wanted and ask their contribution or loan for the exhibition.

"The officers elected at the meeting jesterday were Col. R. T. Durrett, President; Judge James S. Pirtle, Vico-President, and Capt. Thomas Speed, Secretary and Treasurer ${ }^{\circ}$ (8)

The following circular was presented to the members of the Polytechnic Society:

"August 1, 1883

"To the members of the Polytechnic Society.

"This is to advise you that an Academy of History has been formed in the Polytechnic Socloty for the purpose of promoting the study of Kentucky history, and to colloct and preserve books, pemphlets, letters, maps, documents, and papers, and al so rolics and curiositios, such as arms and military equipment, implements of industry, personal and household ornaments, clothing, furniture, portralts, otc., etc., which pertain to or 1llustrate the history of Kentucky and her poople from the earliest times.

"The membership of this Academy is to consist of such members of the Polytechnis Society as choose to unite with 1t. The current expenses of the Academy will be pald by the Polytechnic Soclety, so that no dues will be required of the members.

"It is unnecessary to set forth the value and importance of such an organization in Louisville. The propriety also of having it in connection with the Polytechnic Society is apparent. It w1ll ex-

(8) $\frac{\text { Courier-Journal (Louisville, Kentueky) }}{\text { JuIJ29, } 1883}$

"The Academy of History" 
tend a continuous invitation to all who may be in possession of articles of historic value, to deposit them in a collection where they will be safely preserved, and can be seen by every one interested in the history of Kentucky.

"The co-operation of all the members of the Polytechnic Society is earnestly solicited in this work.

"Members recelving this circular are invited to unite with the Acedemy of History, by sending their names to Thos. Speed, 511 West Green Street, in order that they ma $\bar{y}$ bo enrolled as members. They are also requested to meet the Academy on Saturday, the 4th inst., at 4 o'clock p. m.

$$
\text { R. T. Durrett }
$$

$$
\text { President" }
$$

A newspaper account of the Academy meeting of August 4, 1883, describes the enthusiasm of the partic1pants in planning a display for the Southern Exposition. It discloses plans for erecting in Central Park for the use of the historical society a building designed as a fac-simile of the residence of "Kentucky's first Governor, George Rogers Clark" .

$$
\text { (10) }
$$

(9) Minutes of Meeting of Academy of History of the Polytechnic Society of Kentucky, July 31, 1883

(Office of Clerk of United States District Court of Western District of Kentucky)

(10) Courier-Journal (Louisville, Kentucky) August 5, 1883

"Kontucky Historical Society" 
The minutes of the meeting of the Academy dated August 14, 1883, const 1tute the final record of the organization. There is no evidence that the Academy succooded in attaining its objectives. The organization must have beon short-lived, and doubtless, experienced little success in 1ts undertakings; hovever, it evidentiy formed the nuclous of a subsequent organization that has fulfilled rather adequately the objectives of the former Academy. "On May 15, 1884, Reuben T. Durrett, Richard H. Collins, William Chenault, John Mason Brown, Basil W. Duke, George M. Davie, James S. Pirtle, Thomas W. Bullitt, Alexander P. Humphrey and Thomas Speod, ten of the leading spirits of Loulsville, met at the residence of Colonel Reuben Thomas Durrett 202 East Chestnut street, at the southeast corner of Brook - and organized an association for the purpose of collecting and preserving Kentucky history. Colonel Durrett, the chief instigator of this movement, was a journalist, lawyer, a man of affairs, and a student of Kentucky history. He was elected president, with Thomas Speed secretary and E. T. Halsey treasurer.

"The organization was named The Filson Club. It was so called in honor of John Filson who, one hundred years before, in 1784, published the first history of 
Fentucky - The Discovery, Settlement and Present State of Kentucky. The first paper read before the Club was by Colonel Durrett, and with equal appropriateness an enlargement of this paper was its first Publication John Filson, The First Historian of Kentucky, An Account of H1s Life and Writings". (II)

In 1891 the Club was incorporated. Article

II of its charter reads as follows:

"The principal place of business of this corporation is Loulsville, Kentucky. The general nature of the business to be transacted is the collection and preservation and publication of Historlc matter pertaining to the state of Kontucky and adjacent states; and the cultivation of a taste for historic inquiry and study among its members. The Club shall have porer to collect, maintain and preserve a $11 \mathrm{brary}$ and a museum and to acquire suitable grounds and buildings in which to place them."(12)

(11) Rothert, 0tto A., The Filson Club And Its Activities Filson Club Publications: No. 32

(12) Corporation Book, no. 7, p. 360 Jefferson County Court

"Articles of Incorporation of the Filson Club" Oct. 6, 1891 


\section{SUMMARY}

In summary, the foregoing is as comprehensive a survey of the cultural developments in nineteenth century Loulsville as is possible from the data available to the writer at the present time. The point of view taken throughout has been that such cultural development is to a large degree reflected by the activity of the citizenry of a community in participating in organizations of the type described as distinguished from business and professional activities. The attempt has boen made to review the oarly history and development of such movements; their 1 ifo and activities have been detailed and, wherever such actions occurred, their emergence into existing institutions has been pointed out.

In the course of the century seven library assoclations eppeared at various intervals. Each organization rendered service to the community for a relatively short period of time; however, each organization paved the way for succeoding organizations until, at the "turn of the century", an institution was established that has survived until the present time. The foregoing survey accounts for the existence of the following library associa- 
tions: Louls ville Library Company, 1816; Library of the Kentucky Histor lcal Society, 1838; Mercantile Assoclation Library, 1847; Kentucky Mechanics' Institute, 1854; Young Men's Chr istian Association, 1867; Public Library of Kentucky, 1870; Library of the Polytechnic Soclety of 1878; Louisville Free Public Library, 1902. The Iyceum as a factor in cultural development was short-lived. The apparent interest manifested in this organization in 1831 proves that the citizens of Louls ville were keeping pace in a nation-wide effort to establish the Iyceum as a means of cultural improvement. Scientific advancement movements were expressed through societies based for the most part upon desire to improve knomledge of medical science and instances of popular sclentific lectures. Such activities were evidenced in the subsequent years: 1833, 1835, 1838, 1841-1842, 1851, $1860,1869,1880,1883$.

Literary and musical societies developed intermittently through the century. Marked interest in these fields of improvement manifested itself in the "sixties" and continued on through the century. The tro outstanding organizations that apparently exerted most influence in the community have been the Woman's Club and the Loufsvillo Liederkranz. The existence of the type of musical socie- 
ties appearing in this survey tends to show a desire on the part of participants to develop an appreciation for class1cal music.

The nationalistic cultural groups show active interest on the part of immigrants, particularly the swiss and the German element. In almost every instance music aga in played a dominant part in providing a unifying ageney among Louisville residents of foreign birth.

of the historical associations that were organized during the period included in this survey, one has become a dominating factor in the cultural iffe of Louisville. The ideals and objectives of the Kentucky Historical Soclety of 1838 and the Academy of History of 1883 are being realized through the successful functioning of the Filson club at the present time.

It will be noted that fifty-two movements are taken into account in this survey. Of these organizations the most outstanding that are functioning institutions in present-day Loulsville are: the Loulsville Free Public Iibrary; the Filson Club; the Woman's Club. 
APPENDIX A 


\section{APPENDIX $\underline{A}$}

CONSTITUTION AND BY-IAWS OF THE ACADEMY OF HISTORY OF THE POLYTECHNIC SOCIETY OF KENTUCKY

\section{CONSTITUTION}

I. The name of this Society shall be, The Academy of History of the Polytechnic Soclety of Kentucky.

II. The object of the society shall be to promote the study of the History of Kentucky, and to collect and preserve, books, pamphlets, letters, maps, documents, etc. of and pertaining to Kentucky history and literature: also all articlos, relics and curlosities such as arms and military equipments, furniture, clothing, portraits, etc. etc. which 1llustrate the history of Kentucky and its people from the earliest times.

III. This society shall be composed of such members of the Polytechnic Soclety of Kentucky as may choose to unite with it. 
IV. The officers of the Society shall be a President, Vice-President and Secretary, who shall hold their offices one year and until their successors are elected and qualified. The Secretary shall be also the Treasurer of the Society.

V. The society shall make by-laws for the regulation of its business, and new ones may be made at any regular meeting of the soclety by a majority vote of the members present.

VI. This Constitution may be amended by a vote of the majority of the members of the society.

\section{BY-LAWS}

I. The President of this Soclety shall appoint annualiy an Executive Committeo consisting of two members, of which Executive Comittee the President and secretary shall be ex-officto members. The duty of this Comittee shall be to provide for meetings of this Soclety and for keoping the property of the society, and in general to carry forward and conduct the business of the Society• 
II. The society shall hold meetings at the call of the Executive Comitter.

III. Any meeting called by the Executive Committee shell be a regular meeting, and five members shall constitute a quorum for the transaction of business.

IV. The By-laws of this Soclety may be amended at any meeting of the Academy provided notice of the intended amendment be given to the members previous to the meeting at which the amendment is made. 
APPENDIX $\underline{B}$ 
APPENDIX B

MINUTES OF THE MEETINGS OF THE ACADEMY

OF HISTORY OF THE POLYTECHNIC SOCIETY OF KONTUCKY

Thursday 5 o'clock P. M. July 25, 1883

A number of gentlemen met in the Council rooms of the Polytechnic Soclety of Kentucky pursuent to a notice recelved slgned by E. H. Brown, R. T. Durrett, T. W. Bullitt - requesting a meeting for the purpose of organIzing a "Loan Exhibition" of objects 1llustrating Kentuoky History •

The meeting was called to order by Dr. E. A. Grant who stated the general purpose for which the meeting was called, and on his motion a temporary organization was made by electing R. T. Durrett chairmen and Thos. Speed secretary.

After consultation and suggestions of various propositions Dr. Grant moved that an Historical Academy of the Polytechnic Society of Kentucky be formed This was agreed to. 
Pursuant to motion the chair appointed the following comnittee to draw up a constitution and by-laws Dr. E. A. Grant

Thomas Speod John Mason Brown

E. H. MCDowell

Jas. S. Pirtle

On motion a comittee consisting of B. H. Young, Dr. E. A. Grant and R. C. Tevis was appointed to confer with the officers of the Southern Exposition and ascertain what terms and arrangements can be made in the Exposition of Articles illustrating Kentucky History.

On motion the meeting adjourned to meet again on Saturday July 28th at $40^{\prime}$ clock P. M.

(Clerk of District Court)

Polytechnic Society of Kentucky Academy of History

Saturday July 28th 4 P.M. 1883 Meeting called to order by the chairman R. T. Durret. The report of the comittee appointed to conver with the officers of the Exposition Co. called for and Dr. E. A. 
Grant reported verbally to the effect that the managers of the Exposition desire a statement in writing, to be presented to them, setting forth oxactly what is desired. That they regard the proposition of making a display of articles illustrating Ky. History favorably. The report of the committee appointed to draft a Constitution and Bylaws was called for and report made. It was discussed section by section and after certain alterations and amendments the following Const1tution and Bylaws were unanimously adopted.

The Constitution and bylaws having been adopted, the following offlcers were elected:

$$
\begin{aligned}
& \text { R. T. Durrett - President } \\
& \text { James S. Pirtle Vice-President } \\
& \text { Thomas Speed - Secretary }
\end{aligned}
$$

It was then moved and carried that the secretary be instructed to prepare a circular addressed to the members of the Polytechnic Soclety of Kentucky setting forth the organization of the academy and its object.

It was also moved and carried that a committeo of three be appointed by the President to prepare a circular to be slgned by all the members of this Academy, setting forth the purpose of this organization and request con- 
tribution of material - The circular to be publishod, and also malled to citizens of the state.

The president appointed the following as this Comitteo

$$
\begin{aligned}
& \text { William Winston Fontaine } \\
& \text { James S. Pirtle } \\
& \text { Dr. E. A. Grant }
\end{aligned}
$$

The President appointed the Executive Committoe as provided in the First Bylaws as follows:

$$
\begin{aligned}
& \text { Major E. H. MeDonald } \\
& \text { Dr. E. A. Grant }
\end{aligned}
$$$$
\text { On motion adjourned to meet Tuesday, July }
$$

3lst at $4 \mathrm{P}$. M.

$$
\text { Tuesday July 31st } 4 \text { P.M. } 1883
$$

Academy met pursuant to adjournment

President Durret in the chair.

Wr. Winston Fontaine of the Committee appointed to prepare a circular reported the following which was unanimously accepted 
(printed

circular)

\section{ROOMS OF THE ACADEMY OF HISTORY \\ of The Polytechnic Society of Kentucky}

Loulsvilie, August, 1883.

Dear Sir: On the 28th ultimo there was organized under the charter of the Polytechnic Society of Kentucky an Academy of History.

Our present purpose in addressing you is to call attention to a proposed display during the Southern Exposition of articles illustrating in any manner the history of Kentucky, beginning with the mound-builder and coming down to the present time.

Kentucky is classic ground. World wide is the fame of her ploneers, soldiers, statesmen, jurists, artists, and noble women. Among her historic families were preserved many relles of the men and women who made the early history of our state lilustrious. Many of these relics have been presented to the Polytechnic Soclety of Kentucky, and are regarded by citizens and strangers alike with an interest almost reverential.

This collection is being arranged for exhibition, and we propose to add to 1t, either temporarily or permanently, as the omers may desire, any article that illustrates the manner of life of the prehistoric race populating or roaming over "the dark and bloody ground"; or indicates the characteristics of the rorthy pioneers of our state; or recalls the memory of some sage or hero living during "the Revolutionary perlod" the "War of 1812", the "Mexican", or the late war between the states.

A collection of primitive implements, arms, furniture, clothing, household and personal ornaments, chairs, books, maps, letters, and portraits of distingulshed Kentuckions, or persons connected, either closely or remotely, with the history of Kentucky, and especially histories in manuscripts, local or general scrap-book diaries, journals, blographies, and old papers would be of great interest to the thousands who visit Louisville during the Southern Exposition. 
As a descendant of one of the old families of the state, you doubtless have some relic of bygone days that will be of interest, and recall to mind the deserved fame of your ancestors. If you have not such ob ject yourself, you may know those who have; in elther case, we ask your earnest co-operation in securing small objects for the proposed exhibition.

All due care will be taken for the preservation of such articles and for return of such as are loaned to us.

Please have such articles marked with name of owner, and give its history as far as possible.

Also state whether the article is donated to the permanent collection of the Polytechnic soclety of Kentucky or merely lent for this exhibition; if the latter, state when the article must be returned, and give full directions for its return.

Articles oither lent or donated should be sent by express to Dr. E. A. Grant, secretary of the Polytechnic Soclety of Kentucky, Louisville, Ky. When thus directed the express company will carry these articles free of charge.

Wm. W. Fontaine Thos. Speed Henry Watterson Basil Manly Jas. S. Pirtle Wh. Chenault Thos. W.Bullitt R. H. Porter E. A. Grant Bennett H. YoungJohn Mason Brown R. C. Tevis E. H. McDonald R. T. Durrett James P. Boyce R. J. Menifee

W.W. Haldeman

Richard $\mathrm{H}$. Collins

The Secretary then presented the following circular to the members of the Polytechnic Soclety which was unanimously accepted. 
(Printed olrcular)

ACADEMY ROOMS

Polytechnic Society of Kentucky

August 1, 1883

To the Members of the Polytechnic Society.

This is to advise you that an Academy of History has been formed in the Polytechnic Society for the purpose of promoting the study of Kentucky history, and to collect and preserve books, pamphlets, letters, maps, documents, and pepers, and also relics and curlosities, such as arms and military equipments, implements of industry, personal and household ornaments, clothing, furniture, portralts, etc. etc., which pertain to or iliustrate the history of Kentucky and her people from the earliest times.

The membership of this Academy is to consist of such members of the Polytechnic Society as choose to unite with it. The current expenses of the Academy will be paid by the Polytechnic society, so that no dues will be required of the members.

It is unnecessary to set forth the value and importance of such an organization in Loulsville. The propriety also of having it in connection with the Polytechnic Society is apparent. It will extend a continuous invitation to all who may be in possession of articles of histor 1c value, to deposit them in a collection where they will be safely preserved, and can be seen by every one interested in the history of Kentucky.

The co-operation of all the members of the Polytechnic soclety is earnestly solicited in this work.

Members recelving this clrcular are invited to unite with the Academy of History, by sending the ir names to Thos. Speed, Secretary, 511 West Green Street, in order that they may be enrolled as members. They are also requested to meet the Academy on Saturdey, the 4th inst., at 4 o'clock p. m.

$$
\text { R. T. DURRETT }
$$

Thos. Speed,

President

Secretary

Adjourned to meet Saturday August 4 at 4 P. M. 
Friday August 10th 4 P. M. 1883

The Committee appointed at the last meeting not being ready to report nothing was done at this meeting. Adjourned unt11 Aug. 14, 1883

Tuesday August 14th 4:30 P.M. 1883

Meeting called to order by the Secretary. In the absence of the President E. J. McDermott was called to the chair.

Dr. Grant reported that the Express Companies had declined to transport articles to be used in the Loan Exhibition free of charge. He stated the object of the Academy to the new members who were present.

The proprlety of having some one deliver an address to awaken interest in the work of the academy was discussed and favored.

The matter was left to the judgment of the Executive Committee and the Academy adjourned to assemble again at the call of the Executive Comittee. 
BIBLIOGRAPHY 


\section{BIBLIOGRAPHY}

\section{I. - GENERAL WORKS (BOoks)}

Casseday, Ben - The History of Louisville

HuIl and Brother, Louls vilie, Kentucky, 1852

Durrett, Reuben T. - The Centenary of Loulsville

(Filson Club Publication No. 8 )

John P. Morton and Company, Louisville, Kentucky, 1893

Encyclopaedia Britannica, 14th od., XXII.

Hayes, Cecll Branner - "The American Lyceum"

Office of Education Bulletin -

United States Department of the Interior, 1932, No. 12

Johnston, J. Stoddard - Memorial History of Loulsville Amer lcan Blographical Publishing Company,

Chicago, New York, 1896

Loulsvilie Library Collection

Institution Series, Vol. I

The Loulsvilie Free Public Library,

Louisville, Kentucky, 1935

McMurtrie, H. M. - Sketches of Loulsville and its Environs

S. Penn, Jun. Main Stre et, Louisville, Kentucky, 1819

Noffsinger, John S. - Correspondence Schools, Lyceums, Chatauquas 1926 Rothert, Otto A. - The Filson $\frac{\text { Club }}{\text { Fils on Club Publications, }}$ Its Activities
N2 John P. Mortion and Company, Louisville, Kentucky, 1922

The World Book Encyclopedia, Vol. 16

W. F. Quarrie and Company, Chicago, 1935

Williams, I. A., and Company - History of The Ohio Falls Cities and Their Counties, Cleveland, 0hio, 1882 
II. - CHARTERS, ORDINANCES AND ACTS OF INCORPORATION (City and stato)

Acts of General Assembly of the Commonwealth of Kentucky

$1813-1817$

1833

1835

$1836-1839$

1842

1846

$1850-1851$

$1857-1858$
$1859-1860$

$1865-1866$

$1867-1868$

$1869-1870$

1871

$1877-1878$

$1881-1882$

Book of Incorporation, No. 12, Jefferson County Court Numbers $1,2,3,7,8$ and 9

Charter, Acts and Ordinances of the City of Iouisvilie,

General Ordinance and City Charter 1931 Compllation City of Loulsville, 1931

III. - GOVERNMENT STATISTICS

Statistical Viow of the United States Washington, 1854

The Eighth Census Statistics of the United States in 1860 Washington, 1866

Ninth Census - Vol. I washington, 1872

Statistics of The Population of The United states at the Tenth Census, 1880, Washington, 1883

Report on Population of The United States At The Eloventh Census, 1890, Washington, 1895

Census Reports - Twelfth Census of The United states, 1900, Washington, 1901 
IV. - MAGAZINES

Loulsville Monthly Magazine, Vol. I

August, 1879 - No. 8

November, 1879 - No. 11

December, 1879 - No. 12

The Industrial Revien

August 1, 1883

Published by John W. Ryckman

V. - NEWSPAPERS

The Cour1er-Journal, Louisville, Ky.

July 29, 1883

August 5, 1883

August 12, 1883

December 1; 1883

December 3, 1883

December 1i, 1883

Sept omber 30, 1923

December 29, 1925

The Herald-Post, Louisville, KJ•

February 13; 1927

February 11, 1933

The Louisville Civic Opinion, Louisville, Ky.

July 31, 1926

The Louisvi11e De11y Focus, Louisville, Kentucky

March 23, 1831

Apr11 15, 1831

Apr11 25, 1831

May 5,1831

Octobor 1; 1831

october 8, 1831

November 23, 1831

December 24, 1831 
The Loulsville Da1ly Journal, Lou1sville, Kentucky

$\begin{array}{lrl}\text { November } & 24,1841 \\ \text { No vember } & 29,1841 \\ \text { December } & 13,1841 \\ \text { December } & 18,1841 \\ \text { January } & 5 ; 1842 \\ \text { January } 10 ; 1842 \\ \text { January } 11,1842 \\ \text { January } 17,1842 \\ \text { January } 22,1842 \\ \text { January } 24,1842 \\ \text { Fobruary } 17,1842 \\ \text { February } 21,1842 \\ \text { March } 29,1842\end{array}$

The Louisville Journal, Louisville, Kentucky

July 24, 1866

July 25, 1866

The Louisville Post, Louisville, Kentucky

April 11, 1923

August 31,1925

The Louisvilie Times, Louisville, Kentucky

December 31, 1909

January 8,1930

VI. - PAMPHLETS

Kurze Chronik uber Entstohung

des Schwabischer Unterstutztings - Vereins Loulsville, Kentucky, 1895

Lou1sville Directory, 1832

Publishod by RIchard W. Otis

Louisville, Kentucky, 1832

Visitor's Guide To The Southern

Exposition at Louisvilie, Kentucky

Published by Loulsville Dally Commercial

Louisville, Kentucky, I883 
VII. - RECORDS (Miscellaneous)

Act of Incorporation and By-Laws of the

PoIytechnic Socloty of Kentuck

Loulsvillo Courier-Journat Job Rooms Print, 1881

Constitution and By-Laws of tho

DIckons Mus IcaIs and Dramatic Club

Louisvillo, Kentucky

John P. Mortion and Company, 1896

First Annual Report of the Board of Trustees

OF the Lou1sville Free Library ror the year

बnding August 31, I905

Minutes of meetings of Academy of History

Polytechnic Soclety of Kentucky - MSS.

office of Clerk of U. S. District Court

of Western District of Kentucky

Yearbook of the Woman's Club of Loulsville, 1907 